\title{
Targeting the Cx43 Carboxyl Terminal H2 Domain Preserves Left Ventricular Function Following Ischemia-Reperfusion Injury
}

Jingbo Jiang ${ }^{1,2,7^{*}}$, Joseph A. Palatinus ${ }^{3 *}$, Huamei $\mathrm{He}^{4 *}$, Jegan Iyyathurai ${ }^{5}$, L. Jane Jourdan $^{1}$, Daniel Hoagland ${ }^{1}$, Geert Bultynck ${ }^{5}$, Zhen Wang ${ }^{6}$, Zhiwei Zhang ${ }^{7 \dagger}$, Kevin Schey $^{6}$, Steven Poelzing ${ }^{1,8}$, Francis X. McGowan ${ }^{4}$, Robert G. Gourdie ${ }^{1,8 \dagger}$

${ }^{1}$ Virginia Tech Carilion Fralin Biomedical Research Institute, Center for Heart and Reparative Medicine Research, Virginia Tech, VA, 24016, USA, ${ }^{2}$ Shenzhen Women's and Children's Hospital, Shenzhen, China, ${ }^{3}$ Cedars-Sinai Heart Smidt Institute, CedarsSinai Medical Center, Los Angeles, CA, 90048, ${ }^{4}$ Department of Anesthesiology and Critical Care Medicine, Children Hospital of Philadelphia and University of Pennsylvania, Philadelphia, PA 19104, USA, ${ }^{5}$ KU Leuven, Laboratory of Molecular and Cellular Signaling, Department Cellular and Molecular Medicine, 3000 Leuven, Belgium, ${ }^{6}$ Department of Biochemistry, Vanderbilt University School of Medicine, Nashville 37232, USA, ${ }^{7}$ Departments of Pediatric Cardiology, Guangdong Cardiovascular Institute, Guangdong General Hospital, Guangdong Academy of Medical Sciences, Guangzhou, Guangdong 510100, China, ${ }^{8}$ Department of Biomedical Engineering and Mechanics, Virginia Tech, VA, 24016, USA

Running title: $\mathrm{Cx} 43 \mathrm{H} 2$ targeting preserves heart function

To whom correspondence should be addressed Robert G. Gourdie gourdier@vtc.vt.edu and Zhiwei Zhang drzhangzw@sohu.com, Virginia Tech Carilion Fralin Biomedical Research Institute, Center for Heart and Reparative Medicine Research, Virginia Tech, 2 Riverside Circle, VA, USA, 24016

*These authors contributed equally to this work.

Keywords: $\mathrm{Cx} 43, \mathrm{ZO}-1, \mathrm{PKC} \varepsilon$, phosphorylation, ischemic injury, cardioprotection 


\begin{abstract}
Background: $\alpha \mathrm{CT} 1$ is a 25 amino acid therapeutic peptide incorporating the Zonula Occludens-1 (ZO-1)-binding domain of connexin43 (Cx43) that is currently in Phase III clinical testing for healing chronic skin wounds. In preclinical studies in mice, we reported that $\alpha \mathrm{CT} 1$ reduces arrhythmias and improves ventricular function following cardiac injury, effects that were accompanied by increases in PKCE phosphorylation of Cx43 at serine 368 (pS368). In this study, we undertake a systematic characterization of the molecular mode-of-action of $\alpha \mathrm{CT} 1$ in mitigating the effects of ischemia reperfusion injury on ventricular contractile function.
\end{abstract}

Methods and Results: To determine the basis of $\alpha \mathrm{CT} 1$-mediated increases in pS368 we undertook tandem mass spectrometry of reactants in an in vitro assay of PKC $\varepsilon$ phosphorylation, identifying an interaction between negatively charged amino acids in the $\alpha \mathrm{CT} 1$ Asp-Asp-Leu-Glu-Iso sequence and positively charged lysines (Lys345, Lys346) in a short $\alpha$-helical sequence (H2) within the Cx43 CT domain. In silico modeling provided further support of the specificity of this interaction, leading us to conclude that $\alpha \mathrm{CT} 1$ has potential to directly interact with both $\mathrm{Cx} 43$ and ZO-1. Using surface plasmon resonance, thermal shift and phosphorylation assays, we characterized a series of $\alpha \mathrm{CT} 1$ variant peptides, identifying sequences competent to interact with either ZO-1 PDZ2 or the Cx43 CT, but with limited or no ability to bind both polypeptides. Based on this analysis, it was found that only those peptides competent to interact with $\mathrm{Cx} 43$, but not ZO-1 alone, resulted in increased pS368 phosphorylation in vitro and in vivo. Moreover, in a mouse model of global ischemia reperfusion injury we determined that pre-ischemic infusion only with those peptides competent to bind Cx43 preserved left ventricular (LV) contractile function following injury. Interestingly, a short 9 amino acid (MW=1110) Cx43-binding variant of the original 25 amino acid $\alpha \mathrm{CT} 1$ sequence demonstrated potent LV-protecting effects when infused either before or after ischemic injury.

Conclusions: Interaction of $\alpha \mathrm{CT} 1$ with the $\mathrm{Cx} 43 \mathrm{CT}$, but not ZO-1 PDZ2, explains cardioprotection mediated by this therapeutic peptide. Pharmacophores targeting the Cx43 carboxyl terminus could provide a novel translational approach to preservation of ventricular function following ischemic injury. 


\section{INTRODUCTION}

Heart muscle cells are connected together by large numbers of gap junction (GJ) channels ${ }^{1,2}$. The main subunit protein of GJs in the mammalian ventricle muscle is Connexin 43 (Cx43 encoded by GJA1), which is preferentially localized in intercalated disks - zones of specialized electromechanical interaction between cardiomyocytes ${ }^{3,4}$. Following myocardial infarction in patients with ischemic heart disease, $\mathrm{Cx} 43$ remodels from its normal distribution in muscle tissue bordering the necrotic injury, redistributing from intercalated disks at cardiomyocyte ends to lateral domains of sarcolemma ${ }^{5}$. This process of $\mathrm{Cx} 43$ lateralized remodeling within the cell membrane is a hallmark of ischemic heart disease in humans and is thought to contribute to the arrhythmia-promoting characteristics of the infarct border zone.

Cx43 phospho-status has emerged as a factor of interest in pathogenic assignments of the protein in the wound healing response of cardiac muscle, and other tissues, including skin ${ }^{6}$. Pertinent to GJ remodeling in heart disease, $\mathrm{Cx} 43$ was observed to be retained at intercalated disks during early ischemia ${ }^{7}$. This retention occurred in association with increases in phosphorylation at serine 368 (S368) - a consensus Protein Kinase C (PKC) site in the cytoplasmic Carboxyl Terminal (CT) domain of Cx43. Cx43 S368 phosphorylation has also been linked to reduced activity of $\mathrm{Cx} 43$-formed channels, ${ }^{7-9}$, including undocked hemichannels ${ }^{10}$.

Previously, we showed that a peptide mimetic of the Cx43 Carboxyl Terminus (CT), incorporating its postsynaptic density-95/disks-large/ZZO-1 (PDZ)-binding domain reduced $\mathrm{Cx} 43 \mathrm{GJ}$ remodeling in injury border zone tissues following cryo-infarction of the left ventricle in mice ${ }^{11}$. The decreases in $\mathrm{Cx} 43$ remodeling prompted by treatment with this peptide (termed $\alpha \mathrm{CT} 1$ ) were associated with a decreased propensity of the injured hearts to develop inducible arrhythmias ${ }^{11}$, and sustained improvements in ventricular contractile performance over an 8 -week study period ${ }^{12}$. We further reported that the decreases in $\mathrm{Cx} 43$ lateralization observed in hearts treated with $\alpha \mathrm{CT} 1$ were correlated with increased phosphorylation of S368 ${ }^{11}$, in line with results from other workers linking this post-translational modification to reduced GJ remodeling and cardioprotection ${ }^{7}$.

Initially, we interpreted the induction of increased phosphorylation by $\alpha \mathrm{CT} 1$ as a downstream consequence of the well-characterized property of the peptide to disrupt interactions between $\mathrm{Cx} 43$ and its scaffolding protein ZO-1 ${ }^{13}{ }^{14}$. However, in simple biochemical assays involving purified PKC enzyme, and a Cx43 CT substrate, we went on to show that $\alpha \mathrm{CT} 1$ promoted $\mathrm{S} 368$ phosphorylation in vitro in a dose-dependent manner, without recourse to interaction with $\mathrm{ZO}-1^{11}$. This result raised the prospect that $\alpha \mathrm{CT} 1$ mode-of-action could have at least two independent aspects - one involving inhibition of interaction between $\mathrm{Cx} 43$ and ZO-1 and the other associated with PKCmediated changes in $\mathrm{Cx} 43$ phospho-status.

The details of $\alpha \mathrm{CT} 1$ molecular mechanism is of key translational significance as this therapeutic peptide is presently the subject of testing in the clinic ${ }^{15}$. In Phase II clinical 
trials, $\alpha \mathrm{CT} 1$ showed efficacy in promoting the healing of two types of chronic, slow healing skin wounds ${ }^{16-18}$. $\alpha \mathrm{CT} 1$ is currently in Phase III testing on more than 500 patients, as a treatment for diabetic foot ulcers (GAIT1 trial) ${ }^{19}$. In the present study, we provide details of the molecular mechanism of $\alpha \mathrm{CT} 1$, showing that the protective effects of $\alpha \mathrm{CT} 1$ in ischemic injury to the ventricle is not related to ZO-1 interaction, but is likely associated with binding of the peptide to the $\mathrm{Cx} 43 \mathrm{CT}$, including the $\mathrm{H} 2$ $\alpha$-helical region - a short stretch of the $\mathrm{Cx} 43 \mathrm{CT}$ adjacent to a serine-rich domain that includes S368.

\section{MATERIALS AND METHODS}

\section{Animals}

Male C57BL/6 mice 3-month old were used. The experimental protocols were approved by Institutional Animal Care and Use Committee of Virginia Polytechnic Institute and State University and conform to the NIH guide for the Care and Usage of Laboratory Animals.

\section{Reagents: Peptides, cDNA Expression Constructs, and Antibodies}

Sequences and a brief description of each Cx43-CT-based peptides used are shown in Table 1. Peptides were synthesized and quality checked for fidelity and purity using High Performance Liquid Chromatography and mass spectometry (LifeTein, Hillsborough, NJ). Biotinylated peptides were designed for surface plasmon resonance experiments. Glutathione-S-Transferase (GST) fusion protein constructs composed of the Cx43-CT (pGEX-6-P2 Cx43 CT amino acids 255-382), ZO-1 PDZ1, PDZ2 and PDZ3 were isolated and purified from isopropy-b-D-thiogalactoside (IPTG)-induced BL21 bacteria using standard procedures, described in our previous publications ${ }^{13,14}$, 20. The pGEX6p2-Cx43 CT plasmid was obtained from Prof. Paul L. Sorgen (University of Nebraska Medical Center, USA). Cx43 CT mutant (Cx43 CT-KK/QQ; amino acids Lys345 Lys346 to Gln 345 Gln 346) was developed by site-directed mutagenesis of the pGEX6p2-Cx43 CT plasmid (Agilent technologies, QuikChange II Site-Directed Mutagenesis Kit). The mutation was verified by sequencing. For surface plasmon resonance experiments, the GST was removed using PreScission protease, yielding Cx43 CT protein (wild-type or mutant).

Antibodies: Phospho-Connexin43 (Ser368) (Cell Signaling, 3511S, Danvers, MA), anti-Cx43 produced in rabbit (Sigma: C6219, St. Louis, MO), anti-GST produced in goat (GE, 27457701, Little Chalfont, UK). NeutrAvidin-HRP (Thermo, 31030, MA).

\section{Western Blotting}

Protein samples from all related experiments (PKC and EDC cross-linking assays and Westerns on heart lysates) were processed in lithium dodecyl sulfate sample loading buffer (Bio-Rad, $1610737 \mathrm{CA}$ ), heated at $95^{\circ} \mathrm{C}$ for 5 minutes. Samples from PKC and cross-linking assays were loaded on 18\% Tris-Glycine Stain-Free gels (Bio-Rad, $5678073 \mathrm{CA}$ ); samples from heart lysates were loaded on 10\% Tris-Glycine Stain -Free 
gel (Bio-Rad: $5678033 \mathrm{CA}$ ), resolved by SDS-PAGE, transferred to PVDF FL membrane on a Turbo Transfer System (Bio-Rad, 1704155 CA). $\alpha$ CT1 eluted from cross-linking reactions was detected on blots against biotin with HRP-NeutrAvidin (ThermoFisher, 31001, MA). Signals were detected by HR-based chemiluminescence (ThermoFisher, 34095, MA) and exposed to ECL Chemidoc (Bio-Rad, 1708280 CA) and digitized using Image Lab software (Bio-Rad, 1709692 CA). Detailed methods have also been previously described in our earlier papers ${ }^{11,13,14}$.

\section{Surface Plasmon Resonance}

Efficacy of the interaction of each $\alpha \mathrm{CT} 1$ variant with $\mathrm{Cx} 43 \mathrm{CT}$ or $\mathrm{Cx} 43 \mathrm{CT}-\mathrm{KK} / \mathrm{QQ}$ was tested using surface plasmon resonance (SPR) as described previously ${ }^{20}$. In brief, SPR experiments were performed using a Biacore T200 (GE Healthcare). Equal amounts (response units/RU) of biotin- $\alpha \mathrm{CT} 1$ variants were immobilized on each flow cell of a streptavidin-coated sensor chip (Biacore Inc) using immobilization buffer (in mM: 10 HEPES, 1 EDTA, $100 \mathrm{NaCl}, 0.005 \%$ Tween-20) at $\mathrm{pH} 7.4$. Measurements with wild-type (wt) $\mathrm{Cx} 43 \mathrm{CT}$ and mutant $\mathrm{Cx} 43 \mathrm{CT}-\mathrm{KK} / \mathrm{QQ}$ analytes were done in running buffer (in mM: $10 \mathrm{HEPES}, 100 \mathrm{NaCl}, \mathrm{pH}$ 7.4) at a flow rate of $30 \mu \mathrm{l} / \mathrm{min}$. Binding of analytes were verified at different concentrations, in random order (injection volume $120 \mu \mathrm{l})$. Interacting proteins were then unbound by injection of $10 \mu \mathrm{l}$ regeneration buffer $(50 \mathrm{mM} \mathrm{NaOH}$ and $1 \mathrm{M} \mathrm{NaCl})$ at a flow rate of $10 \mu \mathrm{l} / \mathrm{min}$. Background levels were obtained from a reference cell containing a biotin- control peptide in which the reversed sequence of the last 9 amino acids of $\mathrm{Cx} 43$ was fused to biotin-antennapedia. The RU values obtained with biotin-control peptide were subtracted from the RU values obtained with the different biotin- $\alpha \mathrm{CT} 1$ variants (wild-type or mutant) to generate the different response curves.

\section{PKC-E Cx43 CT S368 phosphorylation Assay}

PKC assay conditions were used to evaluate the PKC- $\varepsilon$ phosphorylation of Cx43-CT substrate at Ser368 as we have described previously, with modifications ${ }^{11} .400 \mathrm{ng} / \mathrm{ml}$ PKC- $\varepsilon$ (Life, 37717L, Carlsbad, CA) was pre-diluted in enzyme dilution buffer (10 mM HEPES pH7.4, 0.01\% CHAPS and 5 mM DTT) and assayed in 20 mM HEPES pH7.4, $10 \mathrm{mM} / \mathrm{L} \mathrm{MgCl}_{2}, 0.1 \mathrm{mM}$ EGTA, $1 X$ lipid mix $(200 \mu \mathrm{g} / \mathrm{ml}$ phosphatidylserine (Avanti Polar Lipids 840032C), $20 \mu \mathrm{g} / \mathrm{ml}$ Diacylglycerol (Avanti Polar Lipids), $1 \mathrm{mM} \mathrm{HEPES}$ pH7.4, 0.03\% CHAPS), $500 \mu \mathrm{M}$ ATP (Sigma, A6419) and $14 \mu \mathrm{g} / \mathrm{ml} \mathrm{Cx43-CT}$ substrate. Kinase assay buffer was supplemented with peptides to produce final concentrations of the reaction constituents, as indicated in figure legends. The mixture was incubated at $37^{\circ} \mathrm{C}$ for 12 minutes and quenched by addition of LDS sample loading buffer (Bio Rad, 1610791). "XT sample buffer" is what was shown on the product label, whereas the component is similar as regular LDS buffer, containing 5-10\% lithium dodecyl sulphate. The reaction was Western blotted for pS368 Cx43 using the PhosphoConnexin43 (Ser368) antibody from Cell Signaling. Proteins were eluted off by stripping buffer (Millipore 2504) and re-probed for total Cx43 using the Sigma antirabbit antibody. Percent phosphorylation (\% P) was quantified using equation 1 and normalized with control group ( $\mathrm{PKC}+$, no peptide added). 
Equation 1: $\% \mathrm{P}=\left(\frac{p S 368 C x 43}{\text { total } C \times 43}\right) \times 100$

\section{EDC Cross-Linking Assay}

To characterize the interaction between the $\mathrm{Cx} 43 \mathrm{CT}$ substrate and peptides, the in vitro kinase assay was performed as above with modification and the constituents then subjected to a cross-linking reaction. The assay buffer used was $20 \mathrm{mM} 3-(\mathrm{N}-$ morpholino) propanesulfonic acid (MOPS), $\mathrm{pH}$ 7.2. The Cx43 CT substrate concentration was $30 \mu \mathrm{g} / \mathrm{ml}$ and peptide concentrations varied as indicated in figure legends. All other reagents present in the kinase reaction were maintained as described above. The reaction was allowed to proceed at $37^{\circ} \mathrm{C}$ for 15 minutes. Afterwards, the carbodiimide crosslinker 1-Ethyl-3-(3-dimethylaminopropyl)carbodiimide $\mathrm{HCl}$ (EDC) (Thermo, 22980) was added to each solution for a final concentration of $20 \mathrm{mM}$. The solution was allowed to cross-link for one hour at room temperature. The reaction was stopped by the addition of $4 \mathrm{X}$ LDS loading buffer, boiled for 5 minutes and subsequently separated by PAGE. The resulting gel was stained in Coomassie brilliant blue (Sigma, B0770) for two hours and destained in a solution of 4\% methanol 7\% acetic acid overnight. Gel bands were subsequently excised for mass spectrometric analysis. For the direct interaction between protein and peptides, PBS, pH 7.5 was used as the coupling buffer. The protein $(50 \mu \mathrm{g} / \mathrm{ml})$ and peptide $(25 \mu \mathrm{M})$ were allowed to react at room temperature for one hour before EDC was added to the reaction mixture. The reaction was Western blotted for Cx43, GST or NeutroAvidin.

\section{Tandem Mass Spectrometry}

Gel bands corresponding to crosslinked $\mathrm{Cx} 43$ and $\alpha \mathrm{CT} 1$ were excised and cut into 1 mm square pieces, destained with three consecutive washes with a 50:50 mixture of 50 $\mathrm{mM}$ ammonium bicarbonate and acetonitrile for 10 mins. $50 \mu \mathrm{L}$ of $10 \mathrm{mM}$ DTT was then added to the gel pieces and the gel pieces were incubated at $56^{\circ} \mathrm{C}$ for one hour. 50 $\mu \mathrm{L}$ of $55 \mathrm{mM}$ iodoacetamide was then added to the sample to alkylate cysteines. The sample was incubated at $25^{\circ} \mathrm{C}$ in the dark for 45 mins. The gel was then dehydrated with three consecutive washes with a 50:50 mixture of $50 \mathrm{mM}$ ammonium bicarbonate and acetonitrile for 10 min and completely dehydrated with $100 \%$ acetonitrile and dried in a speedvac. Gel pieces were rehydrated in 10-15 $\mu \mathrm{L}$ of solution containing $20 \mathrm{ng} / \mu \mathrm{L}$ trypsin (Promega, Madison, WI) in $50 \mathrm{mM}$ ammonium bicarbonate for $15 \mathrm{~min} .30 \mu \mathrm{L}$ of $50 \mathrm{mM}$ ammonium bicarbonate buffer was added to each sample and the samples were incubated at $37^{\circ} \mathrm{C}$ for 18 hours. Peptides were extracted using $20 \%$ ACN/0.1\%TFA once, $60 \%$ ACN/0.1\%TFA twice, and $80 \%$ ACN $/ 0.1 \%$ TFA once. The extracted samples were pooled and dried in a speedvac and reconstituted in $0.1 \%$ formic acid for subsequent LC-MS/MS analysis.

For LC-MS/MS analysis, tryptic peptides were directly separated on a one-dimensional fused silica capillary column $(150 \mathrm{~mm}$ x $100 \mu \mathrm{m})$ packed with Phenomenex Jupiter resin $(3 \mu \mathrm{m}$ mean particle size, $300 \AA$ pore size). One-dimensional liquid chromatography was performed using the following gradient at a flow rate of 0.5 
$\mu \mathrm{L} / \mathrm{min}$ : 0-10 min: $2 \% \operatorname{ACN}(0.1 \%$ formic acid $), 10-50 \mathrm{~min}: 2-35 \% \operatorname{ACN}(0.1 \%$ formic acid), 50-60min: $35-90 \%$ ACN (0.1\% formic acid) balanced with $0.1 \%$ formic acid. The eluate was directly infused into an LTQ Velos mass spectrometer (ThermoFisher, San Jose, CA) equipped with a nanoelectrospray source. The instruments were operated in a data dependent mode with the top five most abundant ions in each MS scan selected for fragmentation in the LTQ. Dynamic exclusion (exclude after 2 spectra, release after $30 \mathrm{sec}$, and exclusion list size of 150) was enabled ${ }^{21}$.

\section{Molecular Modeling}

Structural information for the $\mathrm{Cx} 43 \mathrm{CT}$ domain truncated at $\mathrm{G} 251$ was obtained from the Worldwide Protein Data Bank (DOI:10.2210/pdb1r5s/pdb). The protonated structure of the $\alpha \mathrm{CT} 1$ peptide was obtained by truncating the 9 carboxyl terminal amino acids of the Cx43 CT. In order to model the interaction of the Cx43 CT with $\alpha \mathrm{CT} 1$, the publically available protein-protein docking sever, Zdock (http://zdock.umassmed.edu/help.html) and SWISS-Model were used to model docking of $\alpha \mathrm{CT} 1$ with the $\mathrm{Cx} 43 \mathrm{CT}$ in silico in low-energy conformations. Zdock is a Fast Fourier Transform-based protein docking program. Both $\alpha \mathrm{CT} 1$ and the Cx43 CT were submitted to the ZDOCK server for possible binding modes in the translational and rotational space. Each pose was evaluated using an energy-based scoring function 22.

\section{Protein Thermal Shift (PTS) Assay}

Thermal stability of recombinant GST-PDZ2 or Cx43 CT in the presence or absence of peptides was determined in a 96-well format. Each assay well was composed of 500 $\mu \mathrm{g} / \mathrm{mL}$ protein, $25-100 \mu \mathrm{M}$ of each peptide in PBS buffer, $\mathrm{pH7.4}$. All assays were performed independently six times. Samples were generally prepared in 96-well plates at final volumes of $20 \mu \mathrm{L}$. The fluorescent dye SYPRO Orange (5000X concentrate in DMSO, ThermoFisher, S6650) was added to a final concentration of 8X. Reactions were run on QuantStudio 6 Flex Real-Time PCR system (Applied Biosystems, part of Life Technologies Corporation, CA) according to the manufacturer's recommendations using a melt protocol in 0.05 -degree/sec increments from $25^{\circ} \mathrm{C}$ to $95^{\circ} \mathrm{C}$. The Reporter Dye was "ROX" and quencher Dye and passive reference were selected as "None" for the melt curve according to manufacturer's instructions. The data were analyzed using Protein Thermal Shift ${ }^{\text {TM }}$ Software v1.3 package (Applied Biosystems, CA).

\section{Ischemia-Reperfusion (I/R) Injury Model and LV Contractility}

Male, 3-month-old, body weight $25 \pm 5 \mathrm{~g}$ C57BL/6 mice were used for this study and obtained from Charles River. Left ventricular (LV) function was measured and myocardial ischemia-reperfusion injury ( $\mathrm{I} / \mathrm{R})$ was induced as previously described ${ }^{23}$. Briefly, 15 minutes after the injection of heparin at a dose of 200U/ $10 \mathrm{~g}$ body weight, the mouse was anesthetized by inhalation of isoflurane vapor and subjected to cervical dislocation upon the cessation of respiration. Thoracotomy was immediately performed and the heart excised. The heart was arrested in ice-cold Krebs-Henseleit $(\mathrm{KH})$ buffer (in mM: $25 \mathrm{NaHCO}_{3}, 0.5 \mathrm{EDTA}, 5.3 \mathrm{KCl}, 1.2 \mathrm{MgSO}_{4}, 0.5$ pyruvate, $118 \mathrm{NaCl}, 10$ 
glucose, $2.5 \mathrm{CaCl}_{2}$. The aorta was isolated and cannulated in a Langendorff perfusion system. The heart was then perfused at a constant pressure of $75 \mathrm{mmHg}$ with $\mathrm{KH}$ buffer, which was continually bubbled with $5 \% \mathrm{CO}_{2} / 95 \% \mathrm{O}_{2}$ at $37^{\circ} \mathrm{C}$. Effluent from the Thebesian veins was drained by a thin polyethylene tube (PE-10) pierced through the apex of the LV. A water-filled balloon made of polyvinylchloride film was inserted in the LV and connected to a blood pressure transducer (Harvard Apparatus, 733866, MA). After a 30-minute stabilization period, a balloon volume (BV) generating an LV end-diastolic-pressure (EDP) of $0 \mathrm{mmHg}$, was determined for the heart. The BV was then increased stepwise up through $1,2,5,8,10,12,15,18,20,25,30 \mu 1$ increments of 1-5 $\mu \mathrm{l}$ and contractile performance were recorded for 10 seconds at each step. The indexes of cardiac function were amplified by a Transducer Amplifier Module (Harvard Apparatus, 730065, MA). Data was recorded and analyzed using PowerLab 4/35 (ADInstruments, PL3504, CO) and LabChart V7 (ADInstruments, CO). The BV was then adjusted to set EDP at $\sim 8-10 \mathrm{mmHg}$ and held constant during the ensuing steps of the protocol. Baseline function (determined by EDP at $\sim 8-10 \mathrm{mmHg}$ ) was recorded for 5 minutes. The perfused beating heart were then treated with freshly prepared peptide stocks $(0.2 \mathrm{mM})$, which were infused using syringe pump (Kent Sci, CT) into the perfusion buffer in a mixing chamber above the heart at $5 \%$ of coronary flow rate, to deliver final concentrations of $10-50 \mu \mathrm{M}$ or equivalent vehicle for 20 minutes. At the end of the peptide infusion period hearts were subjected to global, no-flow normothermic ischemia by turning off the perfusion flow for $20 \mathrm{~min}$, followed by a reperfusion phase for $40 \mathrm{~min}$. BV was retaken through the stepwise sequence of 1-5 $\mu 1$ increments between 1 and $30 \mu$, with contractile performance again being recorded for 10 seconds at each step. Cardiac LV function was recorded throughout the procedure. In the case of post-ischemic treatment with $\alpha \mathrm{CT} 11$ peptide, peptide infusion was begun at the initiation of the reperfusion phase, continued for 20 minutes and then contractile function by BV increments was taken as per the other hearts. A set of hearts were freeze-clamped immediately after peptide infusion for Western blotting. The protocol is illustrated in supplemental figure 1.

\section{Laser Scanning Confocal Microscopy and fluorescence quantification of peptide perfused hearts}

LV samples were Langendorff perfused with vehicle control, $\alpha \mathrm{CT} 1$ and $\alpha \mathrm{CT} 11$ solutions as described above and as summarized in supplemental figure 1. Immunofluorescent labeling and detection and quantification of biotinylated peptide were performed as previously described ${ }^{11,14,24}$ on $10 \mu$ m cryosections of tissue. Samples were co-labeled with a rabbit antibody against either connexin43 (Sigma, C6219, 1:250), Dapi and streptavidin conjugated to AlexaFluor 647 (1:4000; ThermoFisher Scientific). Cx43 primary antibodies were detected by goat anti-rabbit AlexaFluor 488 (1:4000; ThermoFisher) secondary antibodies. Confocal imaging was performed using a TCS SP8 confocal microscope. Quantification of fluorescence intensity levels relative to background were performed using NIH ImageJ software.

\section{Statistical Analysis}


Data were expressed as a mean \pm SE unless otherwise noted. Differences among treatments were compared by one-way, two-way or repeated measures ANOVA, followed by post hoc or Mann-Whitney tests, as appropriate. Probability values $p<0.05$ were considered significantly different. No strong evidence of divergence $(p>0.05)$ from normality was found. Data analysis was performed using GraphPad7 (GraphPad Software, LaJolla, CA).

\section{RESULTS}

\section{aCT1 interacts with the Cx43 Carboxyl Terminus H2 domain}

The 25 mer Cx43 mimetic peptide $\alpha \mathrm{CT} 1$ incorporates a 16 -amino acid $\mathrm{N}$-terminal (NT) antennapedia (Antp) sequence followed by the carboxyl terminal (CT)-most 9 amino acids of Cx43: Arg-Pro-Arg-Pro-Asp-Asp-Leu-Glu-Iso or RPRPDDLEI (Fig. 1A and Table 1). The last four amino acids of this sequence (DLEI) comprise a class II PDZbinding motif, which has been shown to mediate a specific interaction with the second of the three PDZ (PDZ2) domains of ZO-1 14, 25, 26. We have previously reported on binding of $\alpha \mathrm{CT} 1$ with ZO-1, and the selectivity of this interaction for the ZO-1 PDZ2 domain over that of ZO-1 PDZ1 and PDZ3 ${ }^{14}$. This selectivity of $\alpha \mathrm{CT} 1$ for ZO-1 PDZ2 is illustrated in Fig. 1B. Consistent with reports by others ${ }^{27}$, deletion of the CT isoleucine of the DLEI binding motif (e.g., as in the $\alpha \mathrm{CT} 1$-I peptide, Table 1) abrogates interaction with ZO-1 PDZ2 (Fig. 1B). We also have previously shown that $\alpha \mathrm{CT} 1$ upregulates a PKC 8 -mediated phosphorylation of $\mathrm{Cx} 43$ at serine 368 (S368) along its primary sequence ${ }^{11}$. This induction of S368 phosphorylation (pS368) by $\alpha \mathrm{CT} 1$ was observed both in vivo in a left ventricular (LV) injury model and in a biochemical assay of PKC $\varepsilon$ activity in vitro ${ }^{11}$.

To identify the molecular determinants of aCT1-induced upregulation of S368 phosphorylation, the zero-length cross-linker 1-ethyl-3-(-3-dimethylaminopropyl) carbodiimide hydrochloride (EDC) was introduced into the in vitro PKCE phosphorylation assay. Zero-length cross-linking covalently bonds directly interacting proteins, enabling identification of partnering proteins in the reaction mixture. The components of the reaction mixture were then separated by SDS-PAGE and tandem mass spectrometry (MS/MS) was performed on the isolated polypeptides (Figs. 1C and 1D). While no evidence for interaction between PKC $\varepsilon$ and $\alpha \mathrm{CT} 1$ was observed, the analysis revealed that a band running just above GST-Cx43 CT corresponded to a covalently linked complex between the $\mathrm{Cx} 43 \mathrm{CT}$ substrate and $\alpha \mathrm{CT} 1$ (Fig. 1C). Moreover, it was determined that a negatively charged glutamic acid (E381) within the PDZ-binding domain of $\alpha \mathrm{CT} 1$, and a pair of aspartic acids (D378, D379), were involved in bonding with a pair positively charged lysines (K) at positions K345 and K346 of the Cx43 CT (Figs. 1C and 1D). The site specificity of this interaction was further confirmed by streptavidin labeling of cross-linked products from kinase reaction mixtures containing Cx43 CT with $\alpha \mathrm{CT} 1$ (Supplemental Fig. 2 left hand blots) or a scrambled peptide (M4) unable to bind Cx43 CT (Supplemental Fig. 2, , middle blots), as well as in reaction mixtures containing a mutated Cx43 CT (GST-Cx43 CT QQ/KK) 
substrate (Supplemental Fig. 2 right hand blots), in which the pair of positively charged lysine residues at K345 and K346 were substituted with neutral glutamines (Q). While no evidence of cross-linking between the scrambled peptide and $\mathrm{Cx} 43 \mathrm{CT}$, or between $\alpha \mathrm{CT} 1$ and the $\mathrm{Cx} 43 \mathrm{CT} \mathrm{QQ} / \mathrm{KK}$ mutant substrate was found, $\alpha \mathrm{CT} 1$ was covalently linked by EDC to $\mathrm{Cx} 43 \mathrm{CT}$ in a concentration-dependent manner.

\section{aCT1 interacts with the Cx43 CT H2 domain}

Structural studies by Sorgen and co-workers have shown that K345 and K346 fall within a short $\alpha$-helical sequence along the Cx43 CT called H2 (for Helix 2) ${ }^{28,} 29$. Figure 2A provides a schematic of the secondary structure of the $\mathrm{Cx} 43 \mathrm{CT}$ showing the location of $\mathrm{H} 2$ (from ${ }^{30}$ ), together with a second nearby stretch of the $\alpha$-helical sequence (H1). To model $\alpha \mathrm{CT} 1: \mathrm{Cx} 43 \mathrm{CT} \mathrm{H} 2$ binding in silico, we submitted the interacting complex to the zDOCK protein modeling server ${ }^{22}$, initially fixing the interaction between the glutamic acid (E) at position -1 of $\alpha \mathrm{CT} 1$ (i.e., E381 in full length Cx43) and the K346 residue of $\mathrm{Cx} 43$ - as predicted by the MS/MS data (i.e., Fig. 1C). The interaction pose shown in Figure $2 \mathrm{~B}$ represents that based on the lowest energy minimization score from over 1800 possible variants of the complex. Using Schrodinger molecular modeling software, and without specifying the initial H2 K346 e381 of $\alpha \mathrm{CT} 1$ bonding constraint, we confirmed that $\alpha \mathrm{CT} 1$ could be optimally configured in an anti-parallel orientation with its available side-chains arrayed along the $\mathrm{H} 2$ sequence (Figs. 2C, D). As indicated by MS/MS, a salt bridge was predicted by this in silico analysis to form between the $\alpha \mathrm{CT} 1$ glutamic acid (E) residue and $\mathrm{Cx} 43$ K346. The modeled interaction further anticipates hydrogen bonding between the side chains of four amino acids arrayed along $\alpha$ CT1 (RPRPDDLEI - amino acids involved in hydrogen-bonds are bolded) and four amino acids between Q340 and E360 of the H2 sequence (Fig. 2D).

\section{Substitution of negatively charged amino acids in $\alpha \mathrm{CT} 1$ results in loss of Cx43 CT binding}

To further probe the $\alpha \mathrm{CT} 1$ complex with $\mathrm{Cx} 43 \mathrm{CT} \mathrm{H} 2$ region, and its consequence for phosphorylation of S368, three variant peptides based on $\alpha \mathrm{CT} 1$ were prepared. In these peptides, negatively charged $\mathrm{E}$ and $\mathrm{D}$ amino acids in the RPRPDDLEI sequence of $\alpha \mathrm{CT} 1$ (i.e., those indicated by MS/MS to be likely involved in Cx43 CT interaction) were substituted by neutral alanines. These $\alpha \mathrm{CT} 1$ variant peptides had the sequences RPRPAALAI, RPRPAALEI, and RPRPDDLAI and are referred to as M1 AALAI, M2 AALEI and M3 DDLAI respectively. First, surface plasmon resonance (SPR) was used to analyze interactions of biotinylated versions of $\alpha \mathrm{CT} 1$ and the $\alpha \mathrm{CT} 1$ variants peptides, immobilized to streptavidin-coated sensor chips, with the Cx43 CT and Cx43 CTKK/QQ proteins as analytes (Figs. 3A-F, Supplemental Fig. 3A, B). The concentration of the analyte was varied between 0.5 and $15 \mu \mathrm{M}$. A concentration-dependent increase in Response Units was observed for Cx43 CT binding to biotin- $\alpha \mathrm{CT} 1$ (Fig. 3A). M1 AALAI showed loss of $\mathrm{Cx} 43 \mathrm{CT}$ binding competence, consistent with having all negatively charged amino acids substituted with alanine (Fig. 3C). Substitution of D378/D379 (M2 AALEI) or E381 (M3 DDLAI) residues by alanines also abrogated 
peptide interaction with Cx43 CT (Figs. 3E, F, Supplemental Fig. 3A, B). In complementary observations, SPR confirmed that the Cx43 CT KK/QQ mutant polypeptide was unable mediate interactions with $\alpha \mathrm{CT} 1$, M1 AALAI, M2 AALEI or M3 DDLAI (Figs. 3B, D, and F), consistent with the pair of lysines at K345 and K346 in $\mathrm{H} 2$ being necessary for interaction between $\mathrm{Cx} 43$ and $\alpha \mathrm{CT} 1$.

\section{Substitution of negatively charged amino acids in $\alpha \mathrm{CT} 1$ fully and partially abrogate interaction with $\mathrm{Cx} 43 \mathrm{CT}$ and ZO-1 PDZ2 respectively}

To further characterize the Cx43-binding characteristics of $\alpha \mathrm{CT} 1$ and the $\alpha \mathrm{CT} 1$ variants, thermal shift assays of peptide:protein interactions were performed (Figure 4). This assay provides quantitative data on the effect of interaction on protein structure with significantly increased or decreased thermal stability in response to temperature cycles in a qPCR machine being diagnostic of potential interaction. For example, in line with the known stabilizing effect of the last 10 amino acids of Cx43 CT on ZO-1 PDZ2 ${ }^{31}, \alpha \mathrm{CT} 1$ concentrations of 25,50 and $100 \mu \mathrm{M}$ increased the melt temperature (i.e., thermal stability) of PDZ2 in a dose-dependent manner (Fig. 4A). Thermal shift assays indicated that the peptides from Table 1 fell into two classes with respect to Cx43 CT interaction - those that provided evidence of interaction with Cx43 CT and those that were Cx43 CT interaction incompetent (Fig. 4B). Consistent with the SPR results, M1 AALAI, M2 AALEI and M3 DDLAI showed no propensity to alter Cx43 CT thermal stability, demonstrating no significant variance from $\mathrm{Cx} 43 \mathrm{CT}$ alone or $\mathrm{Cx} 43 \mathrm{CT}$ in the presence of the scrambled control peptide M4. By contrast, $\alpha \mathrm{CT} 1$, $\alpha \mathrm{CT} 1-\mathrm{I}$ and short variant of $\alpha \mathrm{CT} 1$ comprising the Cx43 CT 9mer sequence RPRPDDLEI ( $\alpha$ CT11), all caused highly significant decreases in melt temperature, in line with interaction of these peptides disrupting protein thermal stability via binding to the $\mathrm{Cx} 43 \mathrm{CT}$.

We also examined the effects of the $\alpha \mathrm{CT} 1$ variants on thermal stability of ZO-1 PD2. Unlike in presence of the parent peptide $\alpha \mathrm{CT} 1$ (Fig. 4A, C), M1 AALAI and M2 AALEI did not alter the melt temperature of PDZ2 (Fig. 4C), not differing significantly from PDZ2 alone, or PDZ2 in the presence of either scrambled peptide (M4) or aCT1-I - the two PDZ2 interaction incompetent peptides (Fig. 1). The results were consistent with M1 AALAI or M2 AALEI having no, or limited, propensity to interact with the ZO-1 domain. However, M3 DDLAI, the most conservative substitution variant, showed evidence of significant interaction with its ZO-1-binding domain, with its effects on the thermal stability of PDZ2 being similar in this assay to those of $\alpha \mathrm{CT} 1$ (Figure 4C). Thus, although M3 DDLAI had no or limited competence to interact with Cx43 CT, this peptide did show evidence of ZO-1 PDZ2-binding activity not significantly different from unmodified $\alpha \mathrm{CT} 1$.

\section{Substitution of negatively charged amino acids in $\alpha \mathrm{CT} 1$ abrogates induction of S368 phosphorylation}

Next, we examined how the mutant peptides performed in the PKC- $\varepsilon$ kinase assay. Unlike $\alpha \mathrm{CT} 1$, neither M1 AALAI, M2 AALEI nor M3 DDLAI increased Cx43 S368 
phosphorylation above levels detected in the absence of peptide (PKC $\varepsilon+$ plus lanes of Fig. 5A), or in the presence of scrambled control peptide (M4, Fig. 5A, B). Quantification of blots indicated that the ability of unmodified $\alpha \mathrm{CT} 1$ to induce S368 phosphorylation was $\sim 3$-fold greater than that of either the $\mathrm{PKC} \varepsilon+$ plus control reaction $(\mathrm{p}<0.001)$ or reactions including M1 AALAI or M4 peptides (Fig. 5C). It was further determined that a 9 amino acid peptide comprising only RPRPDDLEI (i.e., $\alpha \mathrm{CT} 11=$ $\alpha \mathrm{CT} 1$ with its 16 amino acid NT antennapedia sequence truncated) robustly upregulated pS368 levels over control (vs PKC + +plus control <0.001) (Fig. 5C). $\alpha \mathrm{CT} 1-\mathrm{I}$, the ZO1-binding-deficient peptide with $\mathrm{CT}$ isoleucine truncated, also prompted a significant increase in PKC $\varepsilon$-mediated phosphorylation of $\mathrm{Cx} 43 \mathrm{CT}\left(\mathrm{p}<0.05\right.$ vs. PKC $\varepsilon^{+}$plus control). In sum, the results indicated that only those $\alpha \mathrm{CT} 1$-based peptides competent to interact $\mathrm{Cx} 43 \mathrm{CT}$ (i.e., $\alpha \mathrm{CT} 1, \alpha \mathrm{CT} 11$ and $\alpha \mathrm{CT} 1-\mathrm{I}$ ), but not those unable to (i.e., M1 AALAI, M2 AALEI, M3 DDLAI and M4), increased pS368 above control levels. Also, given that M3 DDLAI is unable to induce pS368 increase, but does retain PDZ2 interaction ability, the data suggested that ZO-1-binding activity is dispensable for this phosphorylation.

\section{Only peptides interacting with $\mathrm{Cx} 43 \mathrm{CT}$ protect hearts from ischemic injury}

The biochemical characterizations indicated that $\alpha \mathrm{CT} 1$ is capable of two distinct protein-protein interactions - one with ZO-1 PDZ2 and the other with the Cx43 H2 region. This raised the question as to whether or not the previously characterized effects of $\alpha \mathrm{CT} 1$ in cardiac injury models ${ }^{11,12}$, or indeed its wound healing effects at large ${ }^{16-}$ 18,24 , could be accounted for by one or another of these protein-protein interactions. The series of $\alpha \mathrm{CT} 1$-based variant peptides generated for the present study provided an opportunity to address this question. While $\alpha \mathrm{CT} 1-\mathrm{I}$ is not competent to interact with ZO-1 PDZ2, this $\alpha \mathrm{CT} 1$ variant does bind the Cx43 CT and upregulate S368 phosphorylation. Conversely, while M3 DDLAI showed no ability to bind Cx43 CT, or increase pS368, this peptide retained affinity for the ZO-1 PDZ2 domain. Finally, M1 AALAI showed no evidence of interaction with either PDZ2 or Cx43 CT, and demonstrated no ability to increase pS368 in the in vitro assay. We thus used the variant peptides, together with unmodified $\alpha \mathrm{CT} 1$ in mouse hearts subjected to an ischemiareperfusion (I/R) protocol to systematically assess which aspect of mode-of-action (i.e., peptide interaction with $\mathrm{ZO}-1$ vs. $\mathrm{Cx} 43$ ) accounted for modulation of the I/R injury response by $\mathrm{Cx} 43 \mathrm{CT}$ mimetic peptides.

The protocol and experimental design for the cardiac I/R injury model is illustrated in supplementary Figure 1. In summary, the protocol involved a 20-minute period of no flow ischemia period followed by 40 minutes of reperfusion. For treatment, peptides were infused into hearts over a 20-minute period just prior to the ischemic episode. Representative pressure traces from a vehicle control and $\alpha \mathrm{CT} 1$-treated hearts are shown in Figures 6A and B, from which it can be qualitatively appreciated that preischemic infusion of $\alpha \mathrm{CT} 1$ results in preservation of LV contractile function upon reperfusion relative to vehicle control. 
The effects of the $\alpha \mathrm{CT} 1$ and the $\alpha \mathrm{CT} 1$-variants on left ventricular (LV) systolic and diastolic contractile function showed a striking correlation with the Cx43 CT ability of peptides (Fig. 7). Whereas the non-Cx43 CT interacting peptides M1 AALAI and M3 DDLAI showed no ability to improve recovery of either systolic (Figs. 7A-C) or diastolic (Figs. 7D-F) LV contractile performance during reperfusion, hearts pre-treated with the Cx43 CT-interacting peptides $\alpha \mathrm{CT} 1, \alpha \mathrm{CT} 11$ and $\alpha \mathrm{CT} 1-\mathrm{I}$ demonstrated significant functional recovery after I/R injury, compared to vehicle control mice (Figs. 7A-G). Further, as $\alpha \mathrm{CT} 1-\mathrm{I}$ is able to interact with $\mathrm{Cx} 43 \mathrm{CT}$, but not PDZ2, the results suggested that ZO-1 binding was dispensable for induction of functional cardioprotection. Importantly, all $\mathrm{Cx} 43 \mathrm{CT}$-binding peptides resulted in highly significant 3 to 5 -fold improvements in functional recovery of LV contractile function during reperfusion following ischemic injury relative to vehicle control and the nonCx43 CT interacting peptides (Fig. 7G). In line with the observations of the in vitro kinase assays (Fig. 3), LV samples taken for Western blotting following pre-ischemic treatment of Langendorff-perfused mouse hearts with $\alpha \mathrm{CT} 1, \alpha \mathrm{CT} 11, \alpha \mathrm{CT} 1-\mathrm{I}$ showed significant increases in phosphorylation at the Cx43 PKCE-consensus locus S368 relative to vehicle control perfused hearts (Fig. $7 \mathrm{H}$ ). By contrast, hearts exposed to peptides not competent to interact with Cx43 CT (i.e., M1 AALAI and M3 DDLAI), uniformly showed no propensity to upregulate S368 phosphorylation (Fig. 7H).

\section{Post-Ischemic Treatment with the 9mer peptide aCT11 preserves LV Function}

$\alpha \mathrm{CT} 1$ is in Phase III clinical testing in humans for pathologic skin wounds ${ }^{19}$. The results of figure 7 indicated that pre-treatment with $\mathrm{Cx} 43 \mathrm{CT}$ binding peptides provided protection from injury in the ex vivo model studied. However, to be clinically useful to patients, such as those suffering a myocardial infarction, a drug would typically need to be given after an ischemic insult to the heart, i.e., after a myocardial infarction has been diagnosed. We thus treated hearts during the reperfusion phase following ischemic injury with $\alpha \mathrm{CT} 1$, but determined that this did not result in significant recovery of LV function (data not shown). As $\alpha \mathrm{CT} 1$ showed no evidence of post-infarction efficacy, we decided to explore an alternative approach. It was notable that the most striking recovery of post-ischemic LV function resulted from pre-ischemic treatment with the 9mer Cx43 CT-binding peptide $\alpha \mathrm{CT} 11$ (Table 1). This is illustrated in Figure 7A, where the curve for LV developed pressure for $\alpha \mathrm{CT} 11$ conspicuously overarches that of the other two Cx43-interacting peptides, $\alpha \mathrm{CT} 1$ and $\alpha \mathrm{CT} 1-\mathrm{I}$. This can also be observed in Figure $7 \mathrm{~F}$, where the $\%$ of LV function recovery associated with $\alpha \mathrm{CT} 11$ pre-infusion significantly exceeds that of $\alpha \mathrm{CT} 1$ or $\alpha \mathrm{CT} 1-\mathrm{I}(\mathrm{p}<0.05)$. Based on these results suggestive of increased potency, we sought to determine whether $\alpha \mathrm{CT} 11$ might have a post-ischemic cardioprotective effect.

$\alpha \mathrm{CT} 11$ demonstrated an ability to significantly improve recovery of both systolic (Figs. 8A-C) and diastolic (Figs. 8D-F) LV contractile performance when infused in hearts during the reperfusion following ischemic injury. The level of cardioprotection achieved by this post-ischemic treatment was not as high as when $\alpha \mathrm{CT} 11$ was provided prior to insult, but it was similar to that achieved for pre-ischemic treatment with $\alpha \mathrm{CT} 1$. 
Given that $\alpha \mathrm{CT} 11$ is missing a cell penetration sequence we were curious to determine whether the 9mer peptide (MW=1110 Daltons) was being taken up into cardiomyocytes. We thus examined uptake of $\alpha \mathrm{CT} 11$ in ventricular muscle in mouse hearts that had been perfused with a biotinylated $\alpha \mathrm{CT} 11$ under the protocol summarized in supplementary Figure 1. Cardiomyocytes showed robust uptake of the 9mer $\alpha \mathrm{CT} 11$ sequence, as detected by fluor-conjugated streptavidin (Fig. 8G), and as compared to vehicle control perfused hearts. Relative to vehicle control, quantified levels of uptake of $\alpha \mathrm{CT} 11$ in cells were comparable to those of $\alpha \mathrm{CT} 1$, as indicated by measurement of relative fluorescence intensity levels in ventricular myocardial tissues (Fig. 8H).

\section{DISCUSSION}

This study demonstrates that mimetic sequences incorporating the CT-most nine amino acids of Cx43 (amino acids R374 to I382) complex with the Cx43 CT - including the H2 sequence located between amino acids D340 and D360 of Cx43. This interaction appears to cause disruption of polypeptide structure, which in turn is associated with increases in a PKC-mediated phosphorylation in a serine residue at position 368 of Cx43 - S368. Moreover, evidence is provided that the cardioprotective properties of Cx43 CT mimetic peptides, such as $\alpha \mathrm{CT} 1$, may be explained to a significant degree by their propensity to interact with the $\mathrm{Cx} 43 \mathrm{CT}$. This conclusion is supported by results indicating that a Cx43 CT-binding competent peptides $\alpha \mathrm{CT} 1, \alpha \mathrm{CT} 1-\mathrm{I}$ and $\alpha \mathrm{CT} 11$ preserve LV function following ischemic injury, whereas $\mathrm{Cx} 43$ interaction deficient variants of $\alpha \mathrm{CT} 1, \mathrm{M} 1 \mathrm{AALAI}$ and M3 DDLAI, do not. Interestingly, $\alpha \mathrm{CT} 1$ and H2 represent two spatially distinct sequences on the CT of native Cx43 molecules. Thus, the data point to the possibility of interactions between or within $\mathrm{Cx} 43$ molecules in vivo that may be involved in regulating $\mathrm{Cx} 43$ phosphorylation - potentially doing so by controlling accessibility of $\mathrm{PKC} \varepsilon$ to its $\mathrm{Cx} 43 \mathrm{CT}$ substrate.

Our observations on the relationship between PKC $\varepsilon$-mediated phosphorylation of S368 and cardioprotection are consistent with a longstanding literature 6, 7, 11, 32-39. Phosphorylation of $\mathrm{Cx} 43$ at S368 is correlated with reduced activity of $\mathrm{Cx} 43$-formed hemichannels $6,9,10,40$. Pro-inflammatory and injury spread signals resulting from unregulated opening of hemichannels in the myocyte sarcolemma are thought to be determinants of the severity of ischemia reperfusion damage to the heart ${ }^{41-52}$. Cx43 activity and pS368 phosphorylation events associated with mitochondrial membranes have also been linked to I/R injury severity ${ }^{42,53,54}$. Interestingly, it has been reported that $\mathrm{Cx} 43 \mathrm{CT}$ sequences incorporating the $\mathrm{Cx} 43 \mathrm{H} 2$-binding sequence of interest herein result from alternative translation of the GJA-1 gene (Smyth et al 2013, PMID: 24210816). These include a $20 \mathrm{kDA}$ isoform, termed GJA1-20k, which has been found to be enriched at the interface between mitochondria and microtubules ${ }^{55}$. Similar to the results achieved with synthetic $\mathrm{Cx} 43 \mathrm{CT}$ mimetic sequences here, exogenous provision of GJA1-20k reduces infarct size in mouse hearts subjected to I/R injury ${ }^{56}$. Ongoing experiments would usefully address the extent to which treatment regimens based on $\alpha \mathrm{CT} 1$-based peptides and GJA1-20k share aspects of molecular mechanism. 
The $\mathrm{pH}$-dependent gating of $\mathrm{Cx} 43$-formed channels has been proposed to involve the Cx43 CT in a "ball-and chain"' mechanism ${ }^{57,58}$. The demonstration that the CT-most 10 amino acids of Cx43 (S373-I382 aka CT10) interacts with a region of the cytoplasmic loop domain of $\mathrm{Cx} 43$ referred to as L2, resulting in channel closure under acidic conditions, provides evidence supporting this hypothesis ${ }^{59}$. We demonstrate in the current paper that a near-identical sequence to CT10 contained in $\alpha \mathrm{CT} 1$ (i.e., R374I382), also interacts with the $\mathrm{H} 2$ sequence of $\mathrm{Cx} 43$, doing so via precisely the same negatively charged amino acids required for L2 interaction ${ }^{20}$. In addition to the shared affinity of the CT-most 9 amino acids of Cx43 for L2 and H2, comparison of L2 and $\mathrm{H} 2$ indicate other notable parallels. The $\mathrm{L} 2$ and $\mathrm{H} 2$ sequences of $\mathrm{Cx} 43$ have related secondary structures, both being marked by short stretches of $\alpha$-helix. Further, L2 and $\mathrm{H} 2$ incorporate a pair of lysine (KK) residues. As we demonstrate herein, these lysines are essential for $\alpha \mathrm{CT} 1$ interaction, as substitution of K345 and K346 with neutral glutamines, as in the $\mathrm{Cx} 43 \mathrm{CT} \mathrm{QQ} / \mathrm{KK}$ construct, results in a loss of $\alpha \mathrm{CT} 1$ binding to $\mathrm{H} 2$.

Taken together, the evidence suggests that the nine amino acid CT sequence of $\mathrm{Cx} 43$ mimicked by $\alpha \mathrm{CT} 1$ is a multivalent ligand that participates in a number of proteinprotein interactions. In addition to affinity for $\mathrm{L} 2$ and $\mathrm{H} 2$, this short segment of $\mathrm{Cx} 43$ includes the PDZ-binding-ligand necessary for linkage to ZO-1 ${ }^{14,60,61}$, as well as amino acids required for interaction with 14-3-3 theta ${ }^{62}$. Immediately proximal are consensus recognition sites for AKT (S373) ${ }^{63}$, PKC $\varepsilon$ (S368) ${ }^{64,65}$ and T-cell protein tyrosine phosphatase ${ }^{66}$. The potential for complex patterns of protein-protein interaction occurring within such short stretch of the $\mathrm{Cx} 43$ primary sequence raises intriguing possibilities for future work. Of relevance are questions as to the timing of association of partnering proteins during the $\mathrm{Cx} 43$ life-cycle and the nature of the secondary and tertiary structures involved. With respect to the latter, it would be interesting to explore whether PKC $\varepsilon$ accessibility to $\mathrm{S} 368$ could be governed by intramolecular interactions within $\mathrm{Cx} 43$ or involves intermolecular interactions between $\mathrm{Cx} 43$ molecules. For example, dimers of $\mathrm{Cx} 43$ molecules involving overlapping interactions between the CT-most amino acids of one $\mathrm{Cx} 43$ molecule and the $\mathrm{H} 2$ domain of an adjacent $\mathrm{Cx} 43$ within a connexon, and changes in the avidity of this dimerization, suggests itself as one hypothesis as to how $\mathrm{PKC} \varepsilon$ accessibility to S368 might be regulated.

Our results indicate that the Cx43 CT-binding activity of $\alpha \mathrm{CT} 1$, and not ZO-1 PDZ2 interaction, explains the cardioprotective effects of $\alpha \mathrm{CT} 1$, at least in the model studied here. Whilst Cx43-ZO-1 interaction does not appear to have been a direct factor in the ex vivo model studied, potential roles for ZO-1 in regulating Cx43 phospho-status and hemichannel availability in vivo, including during ischemic injury, should not be discounted. ZO-1 is located at the edge of Cx43 GJs in a specialized zone of cell membrane known as the perinexus ${ }^{63,67,68}$. In earlier studies, we have shown that high densities of hemichannels are found in this peri-junctional region ${ }^{69,70}$ and that PDZbased interactions between ZO-1 and $\mathrm{Cx} 43$ govern the rate at which undocked connexons dock with connexons from apposed cells to form gap junctional channels, 
thereby regulating GJ size, as well as hemichannel availability within the cell membrane ${ }^{13,14}$. Recent work by two other groups have provided data supporting this hypothesis, and have also shown that phosphorylations at Cx43 S368 and S373 are central to how ZO-1 controls the accrual of perinexal hemichannels to the GJ ${ }^{63,71}$. The potential for regulatory interplay between PKC- $\varepsilon$ and ZO-1 at the Cx43-CT is further suggested by earlier studies indicating that the presence of ZO-1 PDZ2 domain in the test tube-based PKC assay efficiently acts as a competitive inhibitor of $\alpha \mathrm{CT} 1$ enhancement of S368 phosphorylation ${ }^{11}$.

A key question raised by our study is whether the $\alpha \mathrm{CT} 1 \mathrm{Cx} 43$-targeting mechanism determined as necessary for preservation of LV function also explains the primary mode-of-action of this therapeutic peptide in other tissues. In skin wounding experiments in mice and pigs, $\alpha \mathrm{CT} 1$ has been shown to reduce inflammation, increase wound healing rates and decrease granulation tissue formation ${ }^{12,}{ }^{24}$. In related observations in Phase II clinical testing of humans, $\alpha \mathrm{CT} 1$ treatment increased the healing rate of slow-healing skin wounds, including diabetic foot ulcers and venous leg ulcers ${ }^{16,18}$. Given the current results in heart, it will be of interest to determine whether the mode-of-action of $\alpha \mathrm{CT} 1$ in wounded skin also involves $\mathrm{Cx} 43 \mathrm{CT}$ interaction and/or increased pS368. As the GAIT1 Phase III clinical trial on $\alpha \mathrm{CT} 1$ moves forward on more than 500 patients with diabetic foot ulcers ${ }^{19}$, such insight on molecular mode-ofaction will be useful in understanding the basis of any clinical efficacy identified in humans, as well as a step in building a safety profile for this therapeutic peptide.

Of further clinical translational note are our findings on the cardioprotective effect of post-ischemic treatment by the short $\alpha \mathrm{CT} 1$ variant $\alpha \mathrm{CT} 11$ - a result that may have clinical implications. Interestingly, $\alpha \mathrm{CT} 11$ does not have a cell penetration sequence, but it nonetheless appears to be internalized by LV cardiomyocytes after intravascular perfusion in the ex vivo model used herein. The mechanism of this cellular uptake is presently under study by our group, but it may be explained by the small size (MW=1110 Daltons) and linear, random coiled-coil 3D structure of $\alpha \mathrm{CT} 11$ - see Figure 2A. Neijssen and co-workers reported that linear peptides with molecular masses below 1800 Daltons readily diffuse through Cx43-formed channels ${ }^{72}$. Given $\alpha \mathrm{CT} 11$ has a molecular mass well below 1800 Daltons, and that hemichannel opening is induced by ischemic insult ${ }^{41}$, the interesting prospect is raised that $\alpha \mathrm{CT} 11$ does not have far to go to reach its target (i.e., the cytoplasmic CT domain of Cx43), potentially doing so by simply transiting open $\mathrm{Cx} 43$ hemichannel pores in the myocyte sarcolemma. Future work would usefully test this hypothesis, as well as undertake further testing of $\alpha$ CT11 in preclinical models of cardiac I/R injury in vivo as a prelude to Phase I testing of this novel therapeutic peptide in human patients with acute myocardial infarction. 


\section{TABLE AND FIGURE LEGENDS}

Table 1. Table of $\mathrm{Cx} 43$ mimetic and variant $(\mathrm{M})$ peptide sequences used. Orange letters indicate the antennapedia cell penetration sequence. Red letters indicate alanine substitutions of negatively charged D and E amino acid residues occurring at the CT of wild-type Cx43. The "Interaction with:" column indicates peptide interaction characterization with $\mathrm{Cx} 43 \mathrm{CT}$ or ZO-1, as determined by EDC cross-linking, molecular modeling, SPR and thermal shift assays provided in figures 1 through 4 and supplemental figures 2 and 3.

\begin{tabular}{|c|c|c|c|c|}
\hline \multirow[t]{2}{*}{ Peptide } & \multirow[t]{2}{*}{ Antennapedia $\quad \mathbf{C x 4 3 ~ C T}$} & \multirow[t]{2}{*}{ Modification } & \multicolumn{2}{|c|}{ Interaction with: } \\
\hline & & & Cx43 CT & ZO-1 PDZ2 \\
\hline$\alpha \mathrm{CT} 1$ & RQPKIWFPNRRKPWKK RPRPDDLEI & Unmodified $\alpha \mathrm{CT} 1$ & +++ & +++ \\
\hline M1 AALAI & RQPKIWFPNRRKPWKK RPRPAALAI & CT DD \& E substituted with As & - & - \\
\hline M2 AALEI & RQPKIWFPNRRKPWKK RPRPAALEI & CT DD substituted with As & $-/+$ & ++ \\
\hline M3 DDLAI & RQPKIWFPNRRKPWKK RPRPDDLAI & CT E substituted with $A$ & + & +++ \\
\hline M4 scram. & RQPKIWFPNRRKPWKK LPAARIAPR & Scrambled control & - & - \\
\hline aCT1-I & RQPKIWFPNRRKPWKK RPRPDDLE & $\mathrm{CT}$ isoleucine deleted & +++ & - \\
\hline aCT11 & RPRPDDLEI & No NT antennapedia seq. & +++ & +++ \\
\hline
\end{tabular}

Figure 1. $\alpha C T 1$ interacts with Zonula Occludens-1 (ZO-1) PDZ2 and the Connexin 43 (Cx43) Carboxyl Terminus (CT). A) Schematics of full length Cx43 and $\alpha \mathrm{CT} 1$ peptide. B) $\alpha \mathrm{CT} 1$ interaction with ZO-1 PDZ domains as indicated by EDC zero-length cross-linking to GST fusion PDZ1, PDZ2 and PDZ3 polypeptides and neutravidin labeling of biotin-tagged peptide at concentrations of 5,25 and $50 \mu \mathrm{M}$. The deletion of the CT Isoleucine (I) in $\alpha \mathrm{CT} 1-\mathrm{I}$ renders this peptide incompetent to interact with the ZO-1 PDZ2 domain. C) Coomassie blue gel of EDC cross-linked products of kinase reaction mixtures containing GST-Cx43 CT and PKC- $\varepsilon$, with $(\alpha \mathrm{CT} 1)$ and without (Vehicle) $\alpha \mathrm{CT} 1$. The fainter band above GST-Cx43 bands (indicated by lines) in the $\alpha \mathrm{CT} 1$ lanes were cut from gels and analyzed by Tandem Mass Spectrometry (MS/MS). The boxes to right of gel show $\mathrm{Cx} 43 \mathrm{CT}$ peptides identified by MS/MS as being cross-linked to $\alpha \mathrm{CT} 1$. D) Tandem mass spectrum of a quintuply charged crosslinked peptide (m/z: 674.1) between Cx43 345-366 (a-chain) and $\alpha \mathrm{CT} 1$ peptide through Cx43 K346 and E8 in $\alpha \mathrm{CT} 1$ (b-chain). Only the b- and y- sequence specific ions are labeled. Arrow indicates ion $\left(\mathrm{b}_{\mathrm{a} 5}{ }^{2+}\right)$ consistent with cross-linkage between Cx43 CT lysine K346 and the glutamic acid (E) residue of $\alpha \mathrm{CT} 1$ at position -1 . 
Figure 2. Molecular modeling of the $\alpha \mathrm{CT} 1$ and $\mathrm{Cx} 43 \mathrm{CT}$ complex. A) Schematics of $\mathrm{Cx} 43$ and the secondary structure of $\mathrm{Cx} 43 \mathrm{CT}$ from amino acid residues Glycine252 (G252) through to Isoleucine 382 (I382). The depiction of secondary structure in 2A has been modified from a diagram originally provided by Sosinsky and co-workers ${ }^{30}$. B) ZDOCK and C) Schrodinger molecular modeling software analysis of the structure of a proposed $\alpha \mathrm{CT} 1-\mathrm{Cx} 43 \mathrm{CT}$ complex. The protonated structure of $\alpha \mathrm{CT} 1$ peptide and Cx43 CT (PDB:1r5s), constrained by a salt-bridge interaction between K346 in the $\mathrm{Cx} 43 \mathrm{CT}$ and the glutamic acid (E) at position -1 of $\alpha \mathrm{CT} 1$. The $\alpha \mathrm{CT} 1-\mathrm{Cx} 43$ interaction shown represents that based on the lowest energy minimization score determined in the model. D) Schrodinger molecular modeling software, a 2D map of $\alpha \mathrm{CT} 1-\mathrm{Cx} 43 \mathrm{CT}$ in anti-parallel orientation showing location of amino acids predicted to bond to each other and the type of bond that is predicted to occur.

Figure 3. $\alpha \mathrm{CT1}$ variants with alanine substitutions of negatively charged amino acids show abrogated ability to bind Cx43 CT (3A-F). SPR was used to analyze interactions of biotin- $\alpha \mathrm{CT} 1$ and biotin- $\alpha \mathrm{CT} 1$ variant peptides, immobilized to streptavidin-coated chips, with the Cx43 CT (Cx43-CT: amino acids 255 to 382) and Cx43 CT-KK/QQ as analytes, respectively. The mean of three runs is plotted for each analyte concentration. The exposure of the sensor chip to the specific analyte is indicated by the gray area. Sensorgrams obtained for: A) Cx43 CT and biotin- $\alpha \mathrm{CT} 1$. B) $\mathrm{Cx} 43 \mathrm{CT}-\mathrm{KK} / \mathrm{QQ}$ and biotin- $\alpha \mathrm{CT} 1$. C) $\mathrm{Cx} 43 \mathrm{CT}$ and biotin-M1 AALAI. D) Cx43 CT-KK/QQ and biotin-M1 AALAI. E) Cx43 CT and biotin-M3 DDLAI. F) Cx43 CTKK/QQ and biotin-M3 DDLAI.

Figure 4. $\alpha \mathrm{CT} 1$ interaction stabilizes PDZ2 and destabilizes Cx43 CT secondary structure. A) Melt curves (top) and first derivative of melt curves (bottom) for ZO-1 PDZ2 at $500 \mu \mathrm{g} / \mathrm{mL}$ in combination $\alpha \mathrm{CT} 1$ at concentrations of 25,50 and $100 \mu \mathrm{M}$. B) Temperature maxima (Tm) from Boltzman curves from left-to-right of Cx43 CT (Cx43$\mathrm{CT}$ : amino acids 255 to 382 ) alone, $\mathrm{Cx} 43 \mathrm{CT}$ in combination with $\alpha \mathrm{CT} 1$, and the $\alpha \mathrm{CT} 1$ variants including: M1 AALAI, M2 AALEI, M3 DDLAI, M4 scrambled, $\alpha \mathrm{CT}-\mathrm{I}$ and $\alpha \mathrm{CT} 11 . \alpha \mathrm{CT} 1, \alpha \mathrm{CT} 1-\mathrm{I}$ and $\alpha \mathrm{CT} 11$ show similar abilities to destabilize (i.e., significantly decrease the $\mathrm{Tm}$ of) $\mathrm{Cx} 43 \mathrm{CT}$. **p $<0.01, * * * \mathrm{p}<0.002, \mathrm{~N}=6$. C) Temperature maxima (Tm) from Boltzman curves from left-to-right of PDZ2 alone, and PDZ2 in combination with $\alpha \mathrm{CT} 1$ and $\alpha \mathrm{CT} 1$ variants including $\alpha \mathrm{CT} 1$ variants including: M1 AALAI, M2 AALEI, M3 DDLAI, M4 scrambled, $\alpha \mathrm{CT}-\mathrm{I}$ and $\alpha \mathrm{CT} 11$. M3 DDLAI, $\alpha \mathrm{CT} 1$, and $\alpha \mathrm{CT} 11$ show similar abilities to stabilize (i.e., significantly increase the Tm of) PDZ2. ${ }^{* *} \mathrm{p}<0.01,{ }^{* * *} \mathrm{p}<0.002, \mathrm{~N}=6$

Figure 5. $\mathrm{Cx} 43$ mimetic peptides that retain $\mathrm{Cx} 43$-binding capability are able to induce phosphorylation of Cx43-CT at serine 368 (S368). A) Blots of Cx43-pS368 (top) and total $\mathrm{Cx} 43$ (bottom) in kinase reactions mixtures including no-kinase controls with substrate (Cx43-CT: amino acids 255 to 382), but no PKC- $\varepsilon$ (PKC-minus); Cx43CT substrate with PKC- $\varepsilon$ (PKC-plus); and mixtures containing PKC- $\varepsilon, \mathrm{Cx} 43 \mathrm{CT}$, and biotin-tagged $\alpha \mathrm{CT} 1$, biotin-tagged $\alpha \mathrm{CT} 1$ mutant peptides with alanine substitutions 
(M1 AALAI, M2 AALEI, M3 DDLAI) and biotin-tagged M4 scrambled. Peptides are at $20 \mu \mathrm{M}$. B) Blots of Cx43-pS368 (top) and total $\mathrm{Cx} 43$ (bottom) in kinase reactions mixtures including no-kinase controls with $\mathrm{Cx} 43 \mathrm{CT}$ substrate, but no PKC- $\varepsilon$ (PKCminus); Cx43-CT substrate with PKC- $\varepsilon$ (PKC-plus); and mixtures containing PKC- $\varepsilon$, Cx43 CT, and biotin- $\alpha \mathrm{CT} 1$, biotin- $\alpha \mathrm{CT} 1-\mathrm{I}$ or biotin- $\alpha \mathrm{CT} 11$ (RPRPDDLEI with no antennapedia sequence at peptide NT) and biotin-M4 scrambled peptide. Peptides are at $20 \mu \mathrm{M}$. C) Chart showing that the ability of unmodified $\alpha \mathrm{CT} 1$ and the $\mathrm{Cx} 43 \mathrm{CT}$ interaction-competent peptides biotin- $\alpha \mathrm{CT} 1-\mathrm{I}$ or biotin- $\alpha \mathrm{CT} 11$ to induce S368 phosphorylation was 3-5 fold greater than that of non-Cx43 CT interacting peptides. * $\mathrm{p}<0.05, * * \mathrm{p}<0.01, * * * \mathrm{p}<0.002, \mathrm{~N}=5 \alpha \mathrm{CT} 1$ and $\mathrm{M} 4$, other peptides $\mathrm{N}=3$.

Figure 6. Pre-Ischemia treatment with peptides competent to interact with $\mathrm{Cx43}$ CT protect hearts from ischemia-reperfusion (I/R) injury. Langendorff $I / R$ protocols were performed on adult mouse hearts instrumented to monitor LV function (protocol in supplemental Fig. 1). Representative pressure traces from hearts from: (A) Vehicle control and (B) $10 \mu \mathrm{M} \alpha \mathrm{CT} 1$ infused hearts. Note that the $\alpha \mathrm{CT} 1$ treatment results in notable recovery of LV function during reperfusion.

Figure 7. Pre-Ischemic treatment with peptides interacting with Cx43 CT protect hearts from ischemia-reperfusion injury in association with increased pS368 in LV myocardium. Langendorff ischemia-reperfusion (I/R) injury protocols were performed on adult mouse hearts instrumented to monitor LV contractility (protocol in supplemental Fig. 1). LV Systolic responses are shown in 7A-C: (A) Plots of left ventricular (LV) systolic developed pressure against balloon volume; (B) LV maximal rate of tension development $(+\mathrm{dP} / \mathrm{dt})$ against balloon volume; (C) Maximal systolic elastance $\left(E_{\max }\right)$ - i.e., the slope from (A); (D) Plots of LV end diastolic pressure (EDP) against balloon volume; (E) Maximal rate of relaxation (-dP/dt) against balloon volume; (F) Stiffness, the reciprocal of the slope from (D); (G) Percentage of LV contractile function recovery post-ischemia relative to baseline level. Data shown are mean \pm S.E. $\mathrm{N}=4-8 .{ }^{*} \mathrm{p}<0.05, * * * \mathrm{p}<0.001, \mathrm{~N}=4-8$ hearts/group. H) Blots of Cx43-pS368 (top) and total Cx43 (bottom) of LV samples infused with peptide for 20 minutes according to the protocol in supplemental figure 1. For hearts used in Western blots, the protocol did not proceed to the ischemia and reperfusion phases, being terminated after the peptide infusion step. Only those peptides competent to interact with $\mathrm{Cx} 43 \mathrm{CT}$ increase pS368 levels relative to total $\mathrm{Cx} 43$ above vehicle control.

Figure 8. Pre- and Post-Ischemic treatment with aCT11 protect hearts from ischemia-reperfusion injury. Langendorff $\mathrm{I} / \mathrm{R}$ protocols were performed on adult mouse hearts instrumented to monitor LV contractility. Protocol in supplemental Fig. 1, except that a 20-minute peptide infusion was begun after ischemic injury at the initiation of reperfusion. (A) Plots of left ventricular (LV) developed pressure against balloon volume; (B) Maximal systolic elastance ( $\left.E_{\max }\right)$, the slope from (A); (C) Maximal rate of tension development $(+\mathrm{dP} / \mathrm{dt})$ against balloon volume; (D) Plots of end 
diastolic pressure (EDP) against balloon volume; (E) Stiffness, the reciprocal of the slope from (D); (F) Maximal rate of relaxation (-dP/dt) against balloon volume . * $\mathrm{p}<0.05, * * * \mathrm{p}<0.001, \mathrm{~N}=4-8$. G) Laser scanning confocal microscopic fields from sections of Vehicle control, $\alpha \mathrm{CT} 1$, and $\alpha \mathrm{CT} 11$ group hearts stained for Cx43 (green), nuclei (DAPI-blue), and Alexa647-conjugated streptavidin (red). H) Average intensities of biotinylated peptide (indicated by streptavidin Alexa647 fluorescence intensity level relative to background) in Vehicle control, $\alpha \mathrm{CT} 1$, and $\alpha \mathrm{CT} 11$ groups. ** $\mathrm{p}<0.05$; not significant (ns) $\mathrm{N}=5$ hearts/group. Scale bar $=5 \mu \mathrm{m}$.

\section{ACKNOWLEDGMENTS:}

We thank Greg Hoeker and Randy Strauss for reading and providing suggestions on the manuscript. We thank Linda Collins for her editorial contribution to this manuscript. Funding: NIH HL56728, RG; HL141855 to SP, HL141855 to RG and SP

Contributions: JJ, JAP, HH, GB, KS, SP, DH, FM and RG were responsible for experimental design and data interpretation.

JJ, JAP, HH, JI, JJ, and ZW conducted experiments.

RG was largely responsible for manuscript preparation, with editing assistance from JJ, HH, GB, DH, ZZ, KS, SP, FM.

Competing interests: $R G$ is a non-remunerated member of the Scientific Advisory Board of FirstString Research who licensed aCT1. He has a modest (under $3 \%$ of total stock) ownership interest in the company. 


\section{SUPPLEMENT}

Supplemental Figure 1. Ischemia reperfusion injury model/protocol. The protocol involved a 20 -minute period of no flow ischemia period followed by 40 minutes of reperfusion, LV contractile function was monitored throughout the whole process. For treatment, peptides were infused into hearts over a 20-minute period just prior to the ischemic episode. Expanded representative pressure traces for each of these phases are shown below.

Supplemental Figure 2. Blots of EDC cross-linked products of kinase reaction mixtures containing GST-Cx43 CT, GST-Cx43 CT QQ/KK in which the lysine (K) residues were mutated to neutral glutamines (Q), PKC- $\varepsilon$ and $\alpha \mathrm{CT} 1$ (at 5, 10 and $25 \mu \mathrm{M}$ ) and a scrambled $\alpha \mathrm{CT} 1$ (M4 scr) variant at the same concentrations. Only $\alpha \mathrm{CT} 1$ is seen to be covalently linked by EDC to $\mathrm{Cx} 43 \mathrm{CT}$ in a concentration-dependent manner.

\section{Supplemental Figure 3. The $\alpha \mathrm{CT} 1$ variant peptide M2 AALEI shows limited} ability to bind Cx43 CT. SPR was used to analyze interactions of biotin-M2 AALEI with the $\mathrm{Cx} 43 \mathrm{CT}$ (A) and Cx43 CT-KK/QQ (B) as respective analytes. The mean of three runs is plotted for each analyte concentration. The exposure of the sensor chip to the specific analyte is indicated by the gray area. 


\section{REFERENCES}

1. Laird DW, Lampe PD and Johnson RG. Cellular Small Talk. Sci Am. 2015;312:707.

2. Desplantez T, Dupont E, Severs NJ and Weingart R. Gap junction channels and cardiac impulse propagation. J Membr Biol. 2007;218:13-28.

3. Jansen JA, van Veen TA, de Bakker JM and van Rijen HV. Cardiac connexins and impulse propagation. J Mol Cell Cardiol. 2010;48:76-82.

4. Martin PE and Evans WH. Incorporation of connexins into plasma membranes and gap junctions. Cardiovasc Res. 2004;62:378-87.

5. Severs NJ, Bruce AF, Dupont E and Rothery S. Remodelling of gap junctions and connexin expression in diseased myocardium. Cardiovasc Res. 2008;80:9-19.

6. Solan JL and Lampe PD. Spatio-temporal regulation of connexin43 phosphorylation and gap junction dynamics. Biochim Biophys Acta. 2018;1860:83-90.

7. Ek-Vitorin JF, King TJ, Heyman NS, Lampe PD and Burt JM. Selectivity of connexin 43 channels is regulated through protein kinase $\mathrm{C}$-dependent phosphorylation. Circ Res. 2006;98:1498-505.

8. Richards TS, Dunn CA, Carter WG, Usui ML, Olerud JE and Lampe PD. Protein kinase $\mathrm{C}$ spatially and temporally regulates gap junctional communication during human wound repair via phosphorylation of connexin43 on serine368. J Cell Biol. 2004; 167:555-62.

9. Lampe PD, TenBroek EM, Burt JM, Kurata WE, Johnson RG and Lau AF. Phosphorylation of connexin43 on serine 368 by protein kinase $\mathrm{C}$ regulates gap junctional communication. J Cell Biol. 2000;149:1503-12.

10. Fiori MC, Figueroa V, Zoghbi ME, Saez JC, Reuss L and Altenberg GA. Permeation of calcium through purified connexin 26 hemichannels. J Biol Chem. 2012;287:40826-34.

11. O'Quinn MP, Palatinus JA, Harris BS, Hewett KW and Gourdie RG. A Peptide Mimetic of the Connexin43 Carboxyl Terminus Reduces Gap Junction Remodeling and Induced Arrhythmia Following Ventricular Injury. Circ Res. 2011.

12. Ongstad EL, O'Quinn MP, Ghatnekar GS, Yost MJ and Gourdie RG. A Connexin43 Mimetic Peptide Promotes Regenerative Healing and Improves Mechanical Properties in Skin and Heart. Adv Wound Care (New Rochelle). 2013;2:5562.

13. Rhett JM, Jourdan J and Gourdie RG. Connexin43 Connexon to Gap Junction Transition Is Regulated by Zonula Occludens-1. Mol Biol Cell. 2011.

14. Hunter AW, Barker RJ, Zhu C and Gourdie RG. Zonula occludens-1 alters connexin43 gap junction size and organization by influencing channel accretion. $\mathrm{Mol}$ Biol Cell. 2005;16:5686-98.

15. Laird DW and Lampe PD. Therapeutic strategies targeting connexins. Nat Rev Drug Discov. 2018.

16. Grek CL, Prasad GM, Viswanathan V, Armstrong DG, Gourdie RG and Ghatnekar GS. Topical administration of a connexin43-based peptide augments healing of chronic 
neuropathic diabetic foot ulcers: A multicenter, randomized trial. Wound Repair Regen. 2015;23:203-12.

17. Grek CL, Montgomery J, Sharma M, Ravi A, Rajkumar JS, Moyer KE, Gourdie RG and Ghatnekar GS. A Multicenter Randomized Controlled Trial Evaluating a Cx43Mimetic Peptide in Cutaneous Scarring. J Invest Dermatol. 2017;137:620-630.

18. Ghatnekar GS, Grek CL, Armstrong DG, Desai SC and Gourdie RG. The effect of a connexin43-based Peptide on the healing of chronic venous leg ulcers: a multicenter, randomized trial. J Invest Dermatol. 2015;135:289-98.

19. ClinicalTrials.gov. A Study of Granexin $(\alpha \mathrm{CT} 1)$ Gel in the Treatment of Diabetic Foot Ulcer. https://clinicaltrialsgov/ct2/show/NCT02667327. 2016;Phase III Clinical Trial.

20. D'Hondt C, Iyyathurai J, Wang N, Gourdie RG, Himpens B, Leybaert L and Bultynck G. Negatively charged residues (Asp378 and Asp379) in the last ten amino acids of the C-terminal tail of $\mathrm{Cx} 43$ hemichannels are essential for loop/tail interactions. Biochem Biophys Res Commun. 2013;432:707-12.

21. Wu SY, Zou P, Fuller AW, Mishra S, Wang Z, Schey KL and McHaourab HS. Expression of Cataract-linked gamma-Crystallin Variants in Zebrafish Reveals a Proteostasis Network That Senses Protein Stability. J Biol Chem. 2016;291:2538725397.

22. Pierce BG, Wiehe K, Hwang H, Kim BH, Vreven T and Weng Z. ZDOCK server: interactive docking prediction of protein-protein complexes and symmetric multimers. Bioinformatics. 2014;30:1771-3.

23. He H, Javadpour MM, Latif F, Tardiff JC and Ingwall JS. R-92L and R-92W mutations in cardiac troponin $\mathrm{T}$ lead to distinct energetic phenotypes in intact mouse hearts. Biophys J. 2007;93:1834-44.

24. Ghatnekar GS, O'Quinn MP, Jourdan LJ, Gurjarpadhye AA, Draughn RL and Gourdie RG. Connexin43 carboxyl-terminal peptides reduce scar progenitor and promote regenerative healing following skin wounding. Regen Med. 2009;4:205-23.

25. Giepmans BN and Moolenaar WH. The gap junction protein connexin43 interacts with the second PDZ domain of the zona occludens-1 protein. Current Biology. 1998;8:931-4.

26. Ambrosi C, Ren C, Spagnol G, Cavin G, Cone A, Grintsevich EE, Sosinsky GE and Sorgen PL. Connexin43 Forms Supramolecular Complexes through NonOverlapping Binding Sites for Drebrin, Tubulin, and ZO-1. PLoS One. 2016;11:e0157073.

27. Jin C, Martyn KD, Kurata WE, Warn-Cramer BJ and Lau AF. Connexin43 PDZ2 binding domain mutants create functional gap junctions and exhibit altered phosphorylation. Cell Commun Adhes. 2004;11:67-87.

28. Bouvier D, Spagnol G, Chenavas S, Kieken F, Vitrac H, Brownell S, Kellezi A, Forge $\mathrm{V}$ and Sorgen PL. Characterization of the structure and intermolecular interactions between the connexin40 and connexin43 carboxyl-terminal and cytoplasmic loop domains. J Biol Chem. 2009;284:34257-71. 
29. Spagnol G, Al-Mugotir M, Kopanic JL, Zach S, Li H, Trease AJ, Stauch KL, Grosely R, Cervantes M and Sorgen PL. Secondary structural analysis of the carboxylterminal domain from different connexin isoforms. Biopolymers. 2016;105:143-62.

30. Sosinsky GE, Solan JL, Gaietta GM, Ngan L, Lee GJ, Mackey MR and Lampe PD. The C-terminus of connexin43 adopts different conformations in the Golgi and gap junction as detected with structure-specific antibodies. Biochem J. 2007;408:375-85.

31. Chen J, Pan L, Wei Z, Zhao Y and Zhang M. Domain-swapped dimerization of ZO-1 PDZ2 generates specific and regulatory connexin43-binding sites. EMBO J. 2008;27:2113-23.

32. Hawat $G$ and Baroudi G. Differential modulation of unapposed connexin 43 hemichannel electrical conductance by protein kinase C isoforms. Pflugers Arch. 2008;456:519-27.

33. Hatanaka T, Shimizu R and Hildebrand D. Expression of a Stokesia laevis epoxygenase gene. Phytochemistry. 2004;65:2189-96.

34. Hund TJ, Lerner DL, Yamada KA, Schuessler RB and Saffitz JE. Protein kinase Cepsilon mediates salutary effects on electrical coupling induced by ischemic preconditioning. Heart Rhythm. 2007;4:1183-93.

35. Miura T, Miki T and Yano T. Role of the gap junction in ischemic preconditioning in the heart. Am J Physiol Heart Circ Physiol. 2010;298:H1115-25.

36. Naitoh K, Yano T, Miura T, Itoh T, Miki T, Tanno M, Sato T, Hotta H, Terashima $\mathrm{Y}$ and Shimamoto K. Roles of Cx43-associated protein kinases in suppression of gap junction-mediated chemical coupling by ischemic preconditioning. Am J Physiol Heart Circ Physiol. 2009;296:H396-403.

37. Jeyaraman MM, Srisakuldee W, Nickel BE and Kardami E. Connexin43 phosphorylation and cytoprotection in the heart. Biochim Biophys Acta. 2012;1818:2009-13.

38. Jozwiak J and Dhein S. Local effects and mechanisms of antiarrhythmic peptide AAP10 in acute regional myocardial ischemia: electrophysiological and molecular findings. Naunyn Schmiedebergs Arch Pharmacol. 2008;378:459-70.

39. Morel S, Christoffersen C, Axelsen LN, Montecucco F, Rochemont V, Frias MA, Mach F, James RW, Naus CC, Chanson M, Lampe PD, Nielsen MS, Nielsen LB and Kwak BR. Sphingosine-1-phosphate reduces ischaemia-reperfusion injury by phosphorylating the gap junction protein Connexin43. Cardiovasc Res. 2016;109:38596.

40. Bao X, Altenberg GA and Reuss L. Mechanism of regulation of the gap junction protein connexin 43 by protein kinase C-mediated phosphorylation. Am J Physiol Cell Physiol. 2004;286:C647-54.

41. Shintani-Ishida K, Uemura K and Yoshida K. Hemichannels in cardiomyocytes open transiently during ischemia and contribute to reperfusion injury following brief ischemia. Am J Physiol Heart Circ Physiol. 2007;293:H1714-20.

42. Boengler K, Stahlhofen S, van de Sand A, Gres P, Ruiz-Meana M, Garcia-Dorado D, Heusch G and Schulz R. Presence of connexin 43 in subsarcolemmal, but not in interfibrillar cardiomyocyte mitochondria. Basic Res Cardiol. 2009;104:141-7. 
43. Morel S and Kwak BR. Roles of connexins in atherosclerosis and ischemiareperfusion injury. Curr Pharm Biotechnol. 2012;13:17-26.

44. Gill R, Kuriakose R, Gertz ZM, Salloum FN, Xi L and Kukreja RC. Remote ischemic preconditioning for myocardial protection: update on mechanisms and clinical relevance. Mol Cell Biochem. 2015;402:41-9.

45. Retamal MA, Schalper KA, Shoji KF, Orellana JA, Bennett MV and Saez JC. Possible involvement of different connexin43 domains in plasma membrane permeabilization induced by ischemia-reperfusion. $J$ Membr Biol. 2007;218:49-63.

46. Gourdie RG, Dimmeler S and Kohl P. Novel therapeutic strategies targeting fibroblasts and fibrosis in heart disease. Nat Rev Drug Discov. 2016;15:620-38.

47. Saez JC, Schalper KA, Retamal MA, Orellana JA, Shoji KF and Bennett MV. Cell membrane permeabilization via connexin hemichannels in living and dying cells. Exp Cell Res. 2010;316:2377-89.

48. Wang N, De Bock M, Decrock E, Bol M, Gadicherla A, Vinken M, Rogiers V, Bukauskas FF, Bultynck $G$ and Leybaert L. Paracrine signaling through plasma membrane hemichannels. Biochim Biophys Acta. 2013;1828:35-50.

49. Li F, Sugishita K, Su Z, Ueda I and Barry WH. Activation of connexin-43 hemichannels can elevate $[\mathrm{Ca}(2+)] \mathrm{i}$ and $[\mathrm{Na}(+)] \mathrm{i}$ in rabbit ventricular myocytes during metabolic inhibition. J Mol Cell Cardiol. 2001;33:2145-55.

50. Kondo RP, Wang SY, John SA, Weiss JN and Goldhaber JI. Metabolic inhibition activates a non-selective current through connexin hemichannels in isolated ventricular myocytes. J Mol Cell Cardiol. 2000;32:1859-72.

51. Stout CE, Costantin JL, Naus CC and Charles AC. Intercellular calcium signaling in astrocytes via ATP release through connexin hemichannels. J Biol Chem. 2002;277:10482-8.

52. Clarke TC, Williams OJ, Martin PE and Evans WH. ATP release by cardiac myocytes in a simulated ischaemia model: inhibition by a connexin mimetic and enhancement by an antiarrhythmic peptide. Eur J Pharmacol. 2009;605:9-14.

53. Boengler K, Dodoni G, Rodriguez-Sinovas A, Cabestrero A, Ruiz-Meana M, Gres P, Konietzka I, Lopez-Iglesias C, Garcia-Dorado D, Di Lisa F, Heusch G and Schulz R. Connexin 43 in cardiomyocyte mitochondria and its increase by ischemic preconditioning. Cardiovasc Res. 2005;67:234-44.

54. Rodriguez-Sinovas A, Boengler K, Cabestrero A, Gres P, Morente M, Ruiz-Meana M, Konietzka I, Miro E, Totzeck A, Heusch G, Schulz R and Garcia-Dorado D. Translocation of connexin 43 to the inner mitochondrial membrane of cardiomyocytes through the heat shock protein 90-dependent TOM pathway and its importance for cardioprotection. Circ Res. 2006;99:93-101.

55. Fu Y, Zhang SS, Xiao S, Basheer WA, Baum R, Epifantseva I, Hong T and Shaw RM. Cx43 Isoform GJA1-20k Promotes Microtubule Dependent Mitochondrial Transport. Front Physiol. 2017;8:905.

56. Basheer WA, Xiao S, Epifantseva I, Fu Y, Kleber AG, Hong T and Shaw RM. GJA1-20k Arranges Actin to Guide Cx43 Delivery to Cardiac Intercalated Discs. Circ Res. 2017;121:1069-1080. 
57. Morley GE, Taffet SM and Delmar M. Intramolecular interactions mediate $\mathrm{pH}$ regulation of connexin43 channels. Biophysical Journal. 1996;70:1294-302.

58. Moreno AP, Chanson M, Elenes S, Anumonwo J, Scerri I, Gu H, Taffet SM and Delmar M. Role of the carboxyl terminal of connexin43 in transjunctional fast voltage gating. Circ Res. 2002;90:450-7.

59. Ponsaerts R, De Vuyst E, Retamal M, D'Hondt C, Vermeire D, Wang N, De Smedt H, Zimmermann P, Himpens B, Vereecke J, Leybaert L and Bultynck G. Intramolecular loop/tail interactions are essential for connexin 43-hemichannel activity. Faseb J. 2010. 60. Toyofuku T, Yabuki M, Otsu K, Kuzuya T, Hori M and Tada M. Direct association of the gap junction protein connexin-43 with ZO-1 in cardiac myocytes. $J$ Biol Chem. 1998;273:12725-31.

61. Giepmans Bn and Moolenaar Wh. The gap junction protein connexin43 interacts with the second PDZ domain of the zona occludens-1 protein. Current Biology. 1998;8:931-4.

62. Smyth JW, Zhang SS, Sanchez JM, Lamouille S, Vogan JM, Hesketh GG, Hong T, Tomaselli GF and Shaw RM. A 14-3-3 mode-1 binding motif initiates gap junction internalization during acute cardiac ischemia. Traffic. 2014;15:684-99.

63. Dunn CA and Lampe PD. Injury-triggered Akt phosphorylation of Cx43: a ZO-1driven molecular switch that regulates gap junction size. J Cell Sci. 2014;127:455-64.

64. Doble BW, Ping P and Kardami E. The epsilon subtype of protein kinase C is required for cardiomyocyte connexin-43 phosphorylation. Circ Res. 2000;86:293-301. 65. Srisakuldee W, Jeyaraman MM, Nickel BE, Tanguy S, Jiang ZS and Kardami E. Phosphorylation of connexin-43 at serine 262 promotes a cardiac injury-resistant state. Cardiovasc Res. 2009;83:672-81.

66. Li H, Spagnol G, Naslavsky N, Caplan S and Sorgen PL. TC-PTP directly interacts with connexin43 to regulate gap junction intercellular communication. J Cell Sci. 2014;127:3269-79.

67. Barker RJ, Price RL and Gourdie RG. Increased association of ZO-1 with connexin43 during remodeling of cardiac gap junctions. Circ Res. 2002;90:317-24.

68. Baker SM, Kim N, Gumpert AM, Segretain D and Falk MM. Acute internalization of gap junctions in vascular endothelial cells in response to inflammatory mediatorinduced G-protein coupled receptor activation. FEBS Lett. 2008;582:4039-46.

69. Rhett JM, Ongstad EL, Jourdan J and Gourdie RG. Cx43 associates with $\mathrm{Na}(\mathrm{v}) 1.5$ in the cardiomyocyte perinexus. J Membr Biol. 2012;245:411-22.

70. Veeraraghavan R, Lin J, Hoeker GS, Keener JP, Gourdie RG and Poelzing S. Sodium channels in the $\mathrm{Cx} 43$ gap junction perinexus may constitute a cardiac ephapse: an experimental and modeling study. Pflugers Arch. 2015.

71. Thevenin AF, Margraf RA, Fisher CG, Kells-Andrews RM and Falk MM. Phosphorylation regulates connexin43/ZO-1 binding and release, an important step in gap junction turnover. Mol Biol Cell. 2017;28:3595-3608.

72. Neijssen J, Herberts C, Drijfhout JW, Reits E, Janssen L and Neefjes J. Crosspresentation by intercellular peptide transfer through gap junctions. Nature. 2005;434:83-8. 


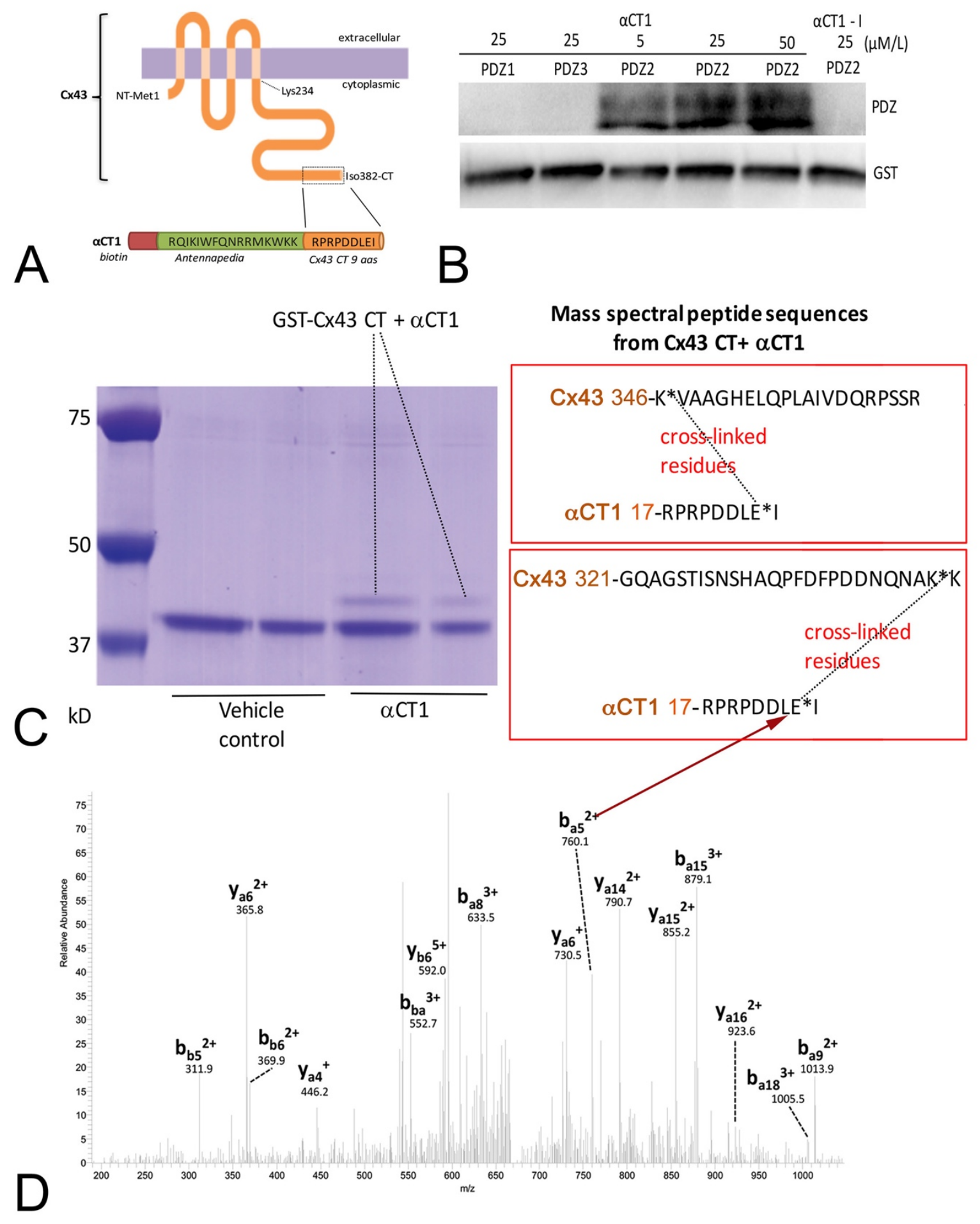

Figure 1 

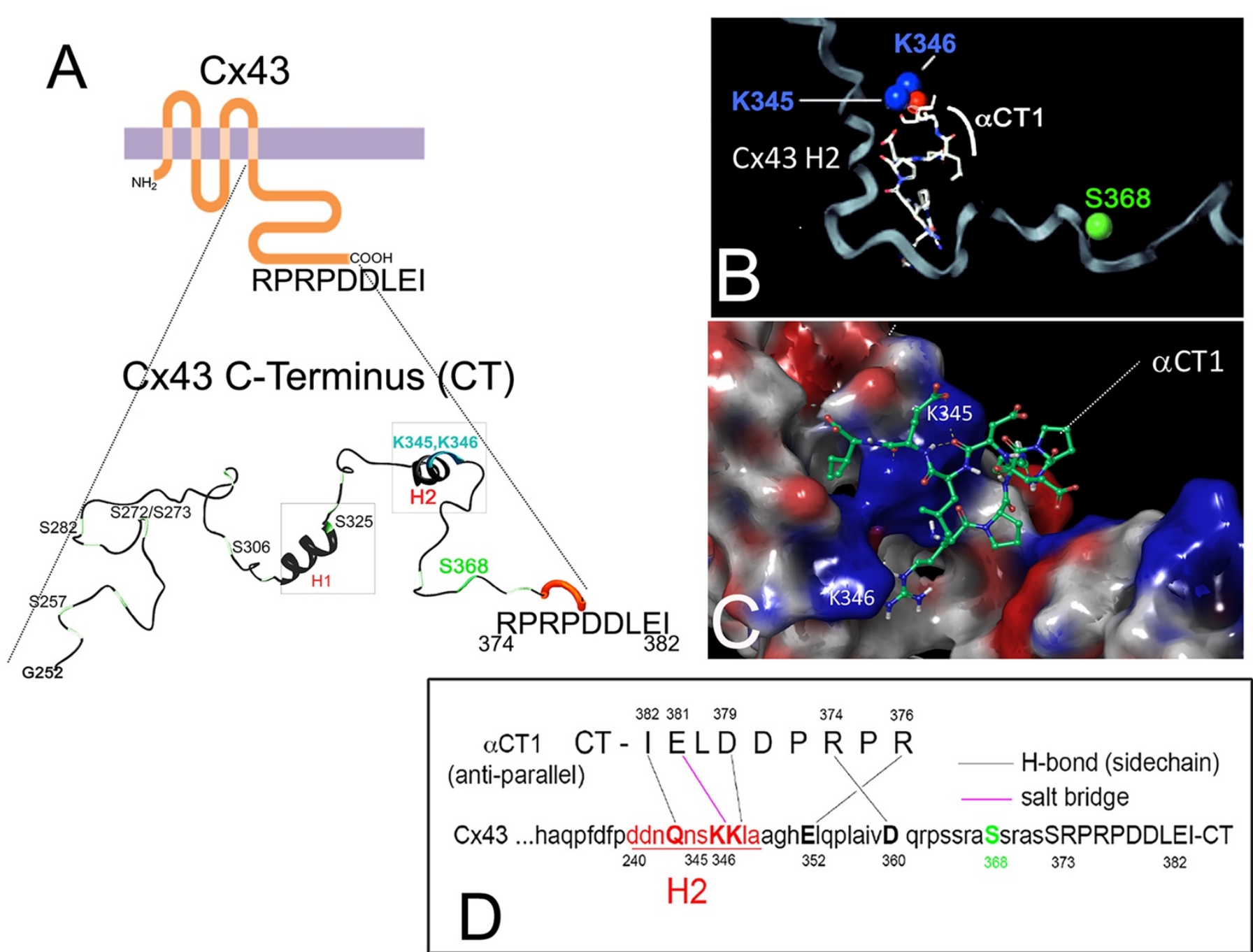

Figure 2 

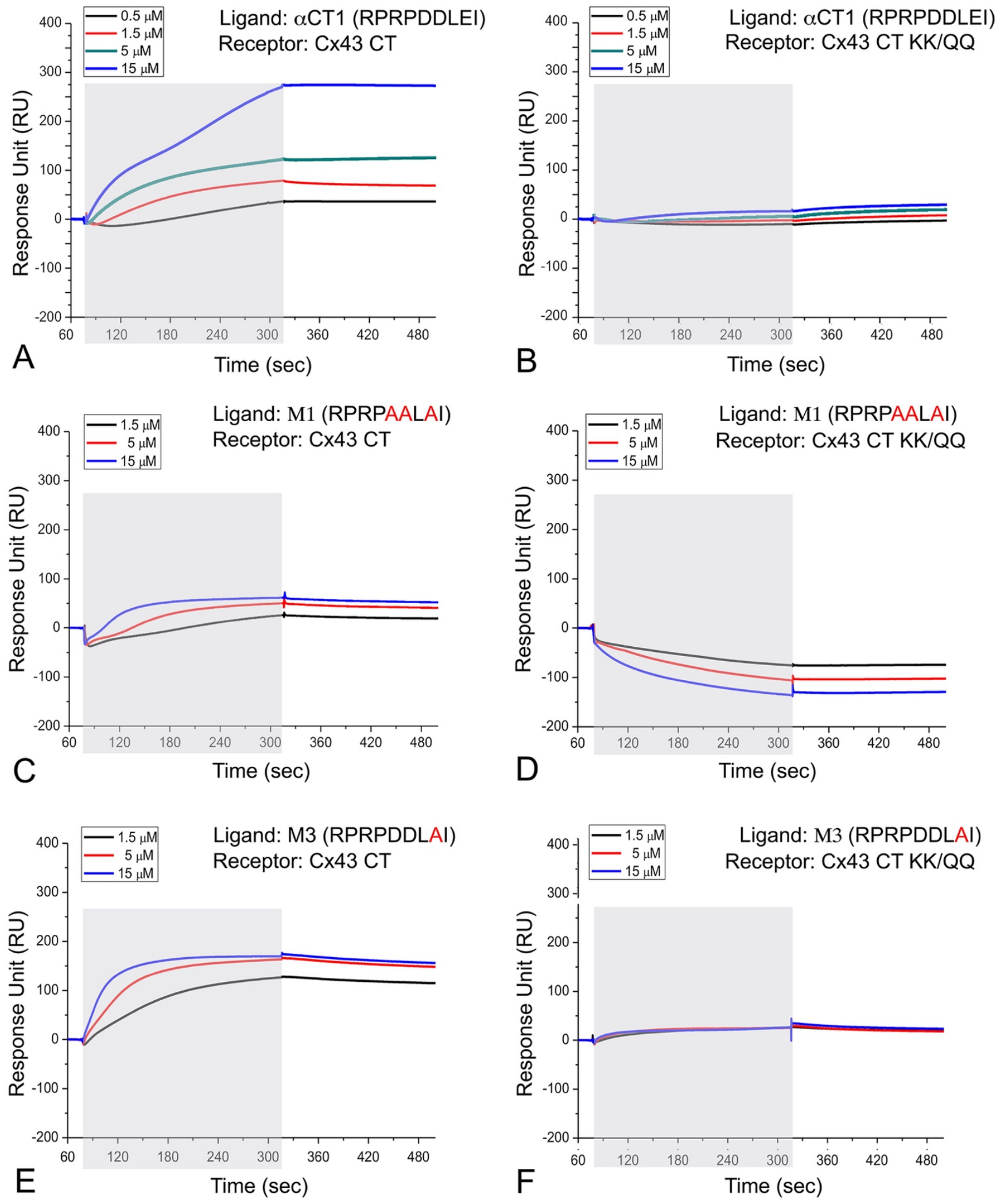

Figure 3 
bioRxiv preprint doi: https://doi.org/10.1101/668509; this version posted June 12, 2019. The copyright holder for this preprint (which was

not certified by peer review) is the author/funder, who has granted bioRxiv a license to display the preprint in perpetuity. It is made available under aCC-BY-NC-ND 4.0 International license.

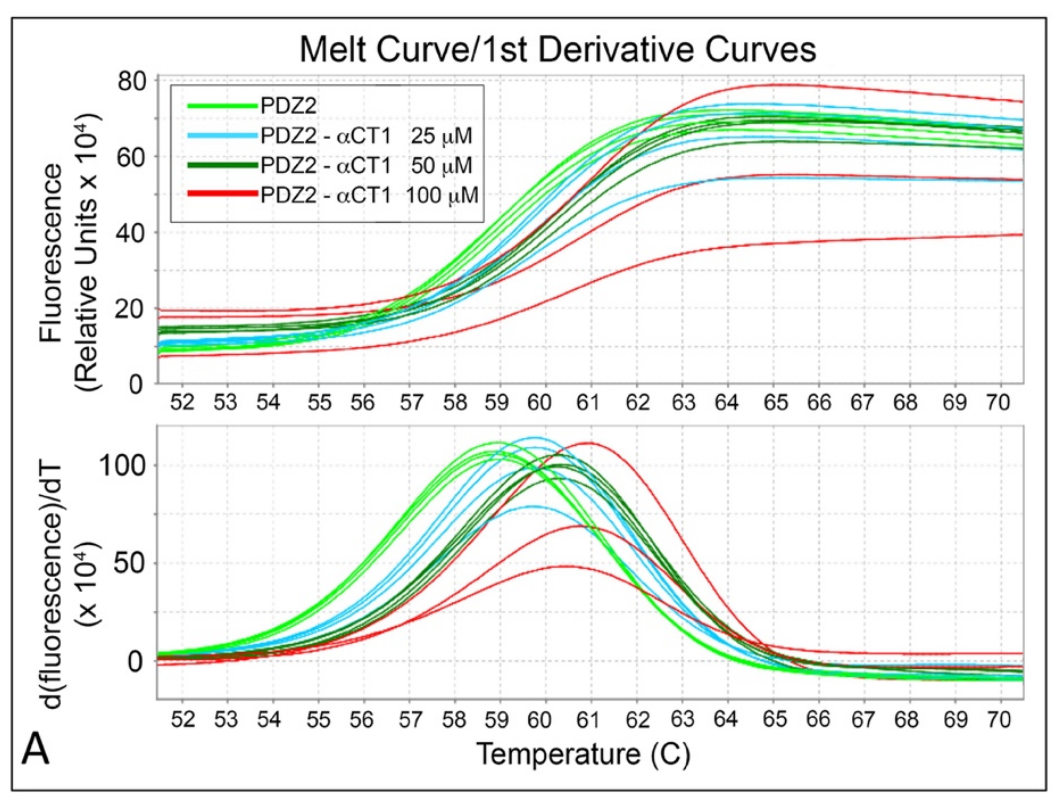

C
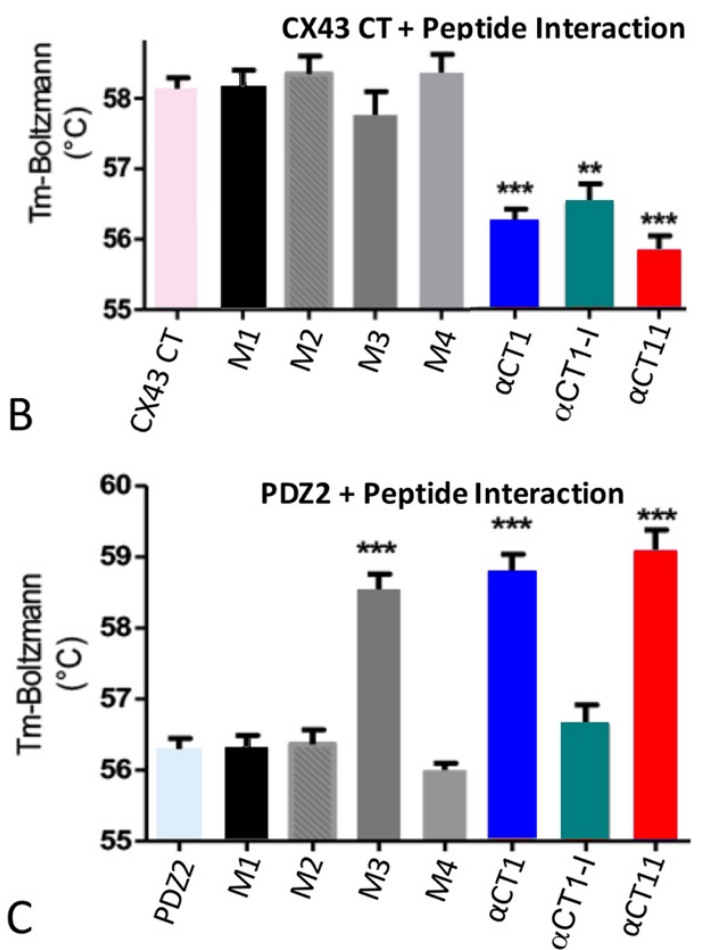

Figure 4 


\section{A}
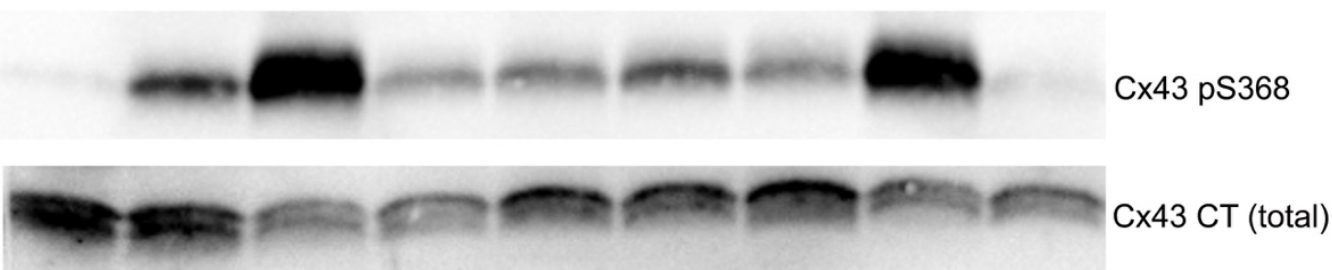

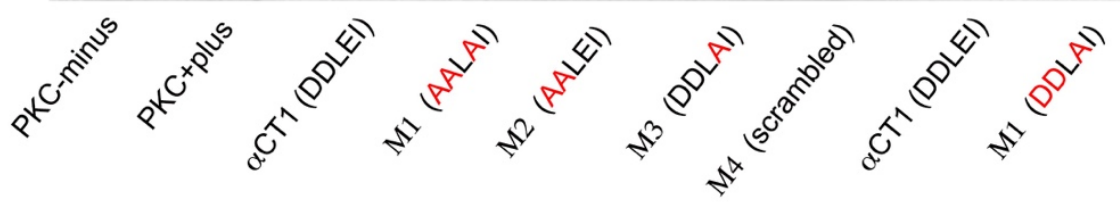

B

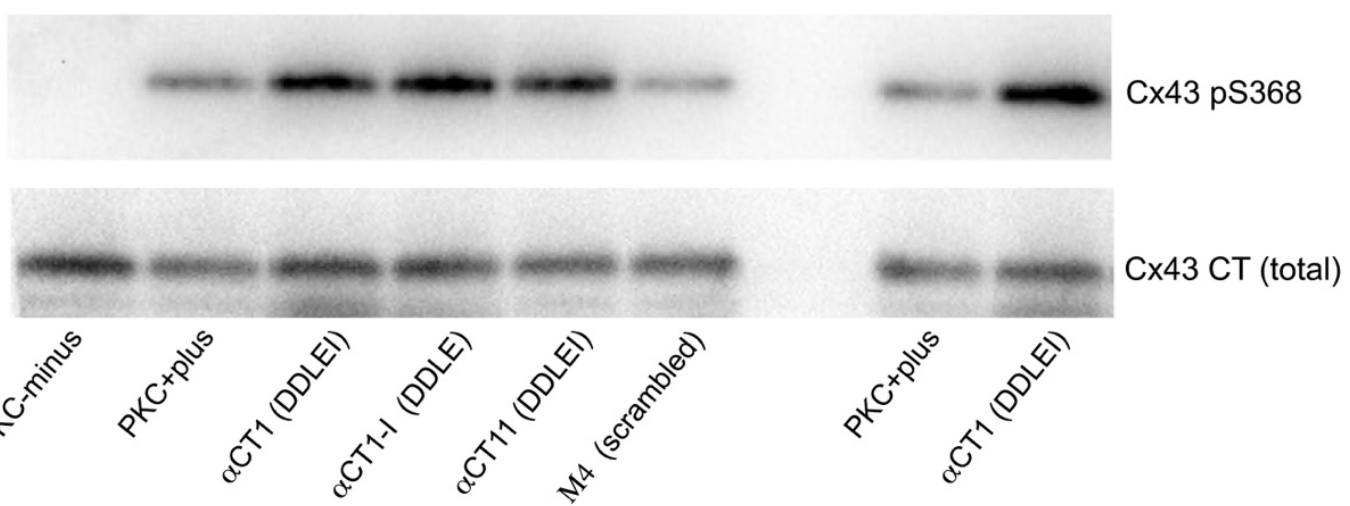

C

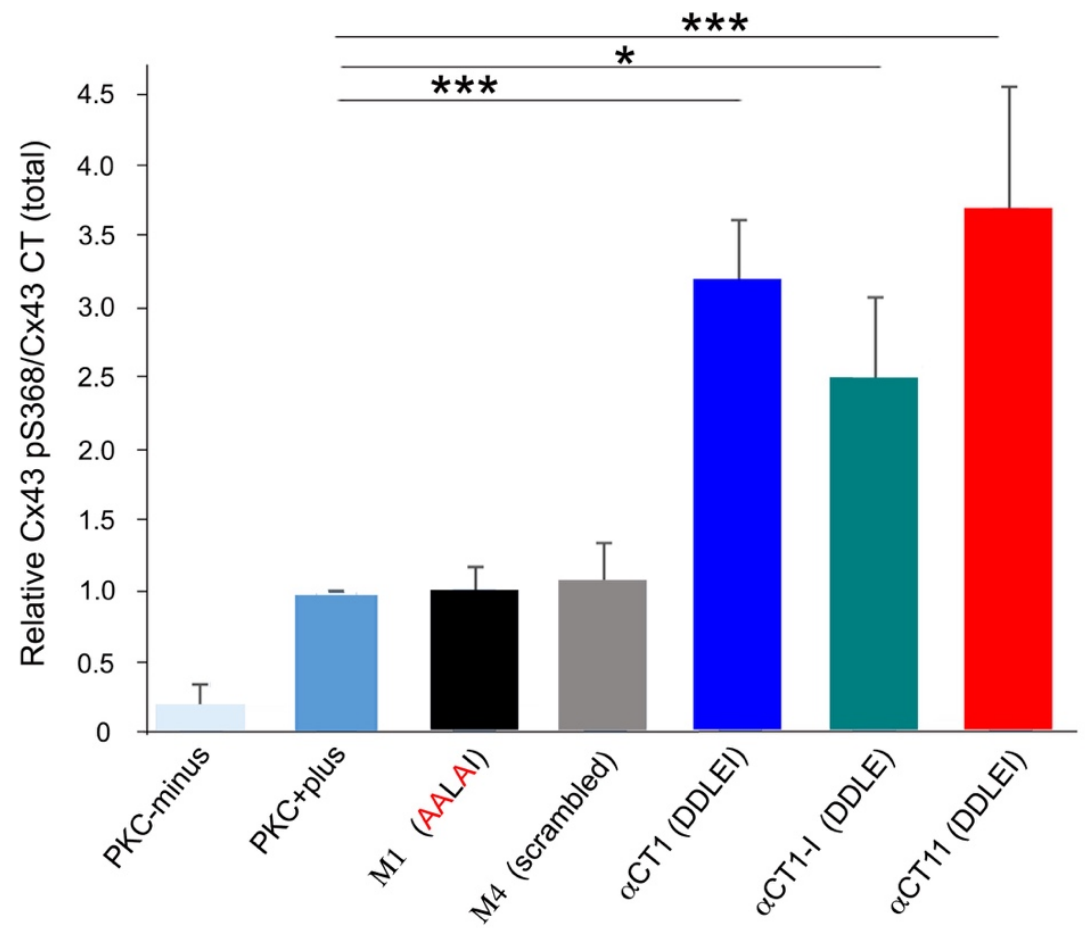

Figure 5 
bioRxiv preprint doi: https://doi.org/10.1101/668509; this version posted June 12,2019 . The copyright holder for this preprint (which was

not certified by peer review) is the author/funder, who has granted bioRxiv a license to display the preprint in perpetuity. It is made available under aCC-BY-NC-ND 4.0 International license.

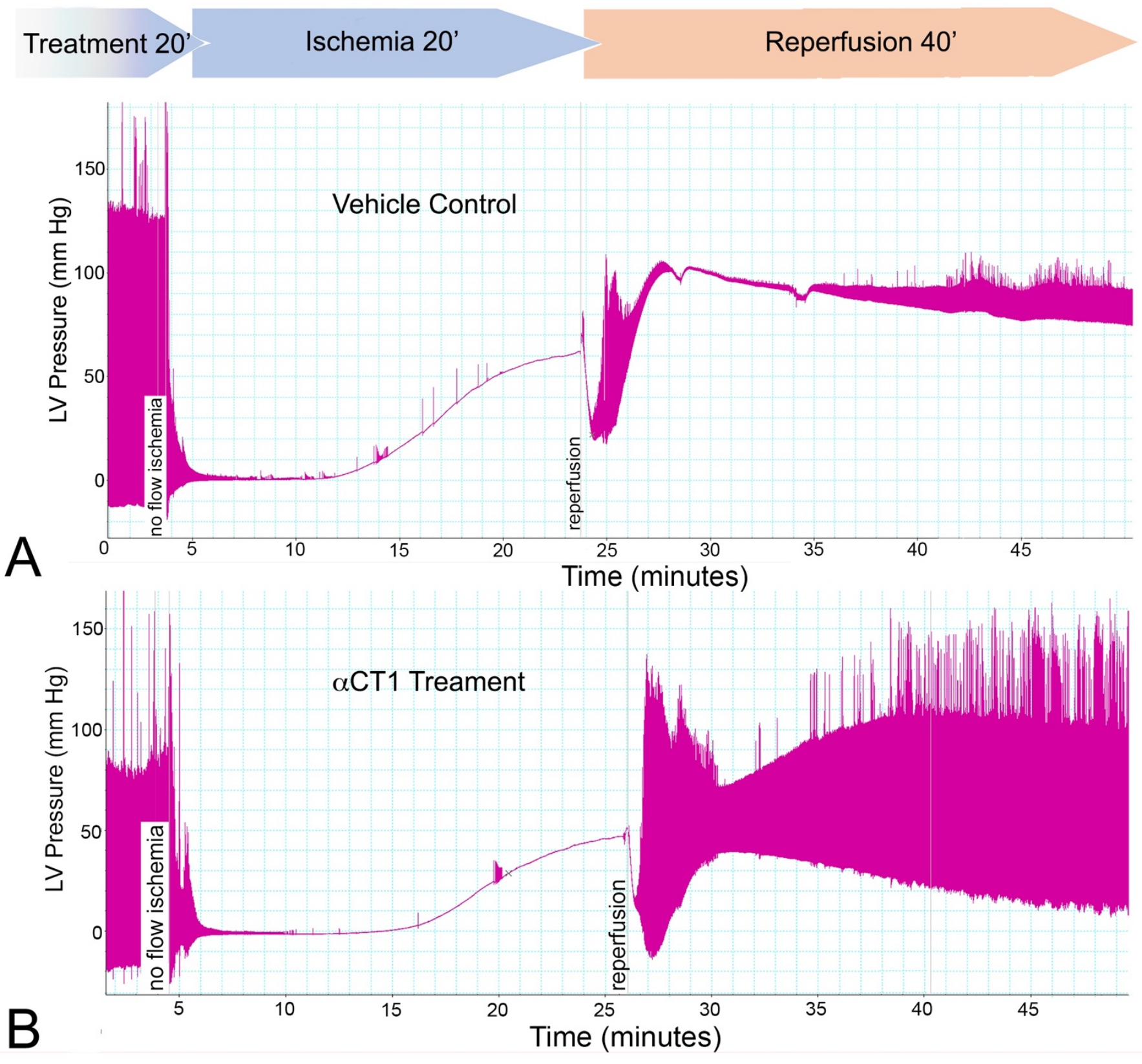

Figure 6 
bioRxiv preprint doi: https://doi.org/10.1101/668509; this version posted June 12, 2019. The copyright holder for this preprint (which was

not certified by peer review) is the author/funder, who has granted bioRxiv a license to display the preprint in perpetuity. It is made available under aCC-BY-NC-ND 4.0 International license.
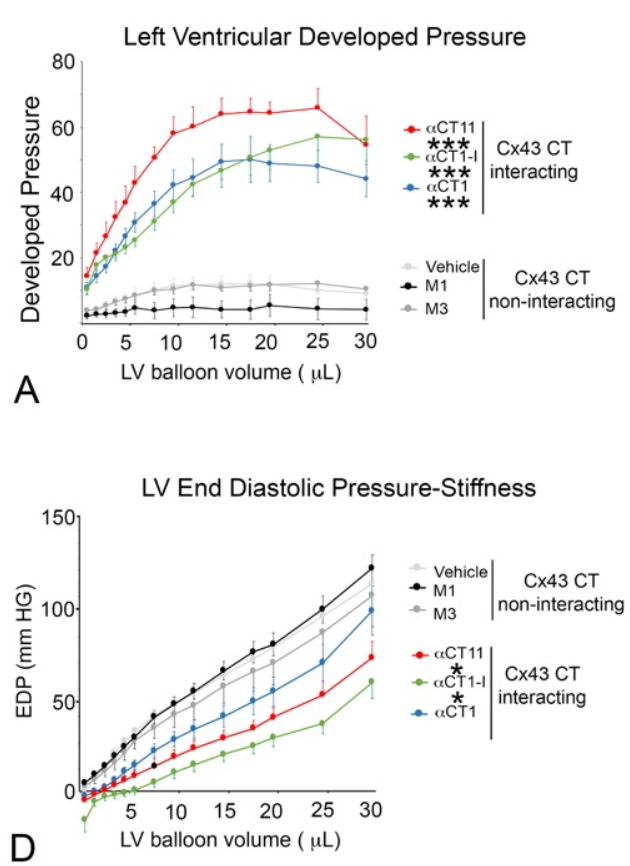

\% Left Ventricular Recovery after ischemia

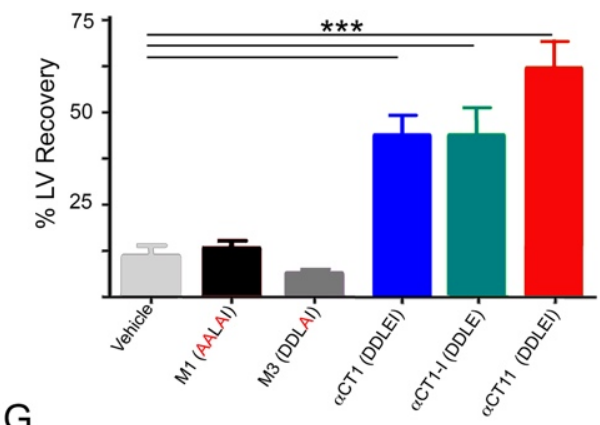

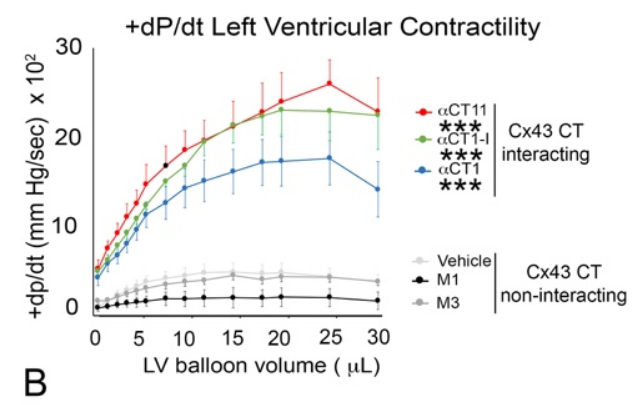
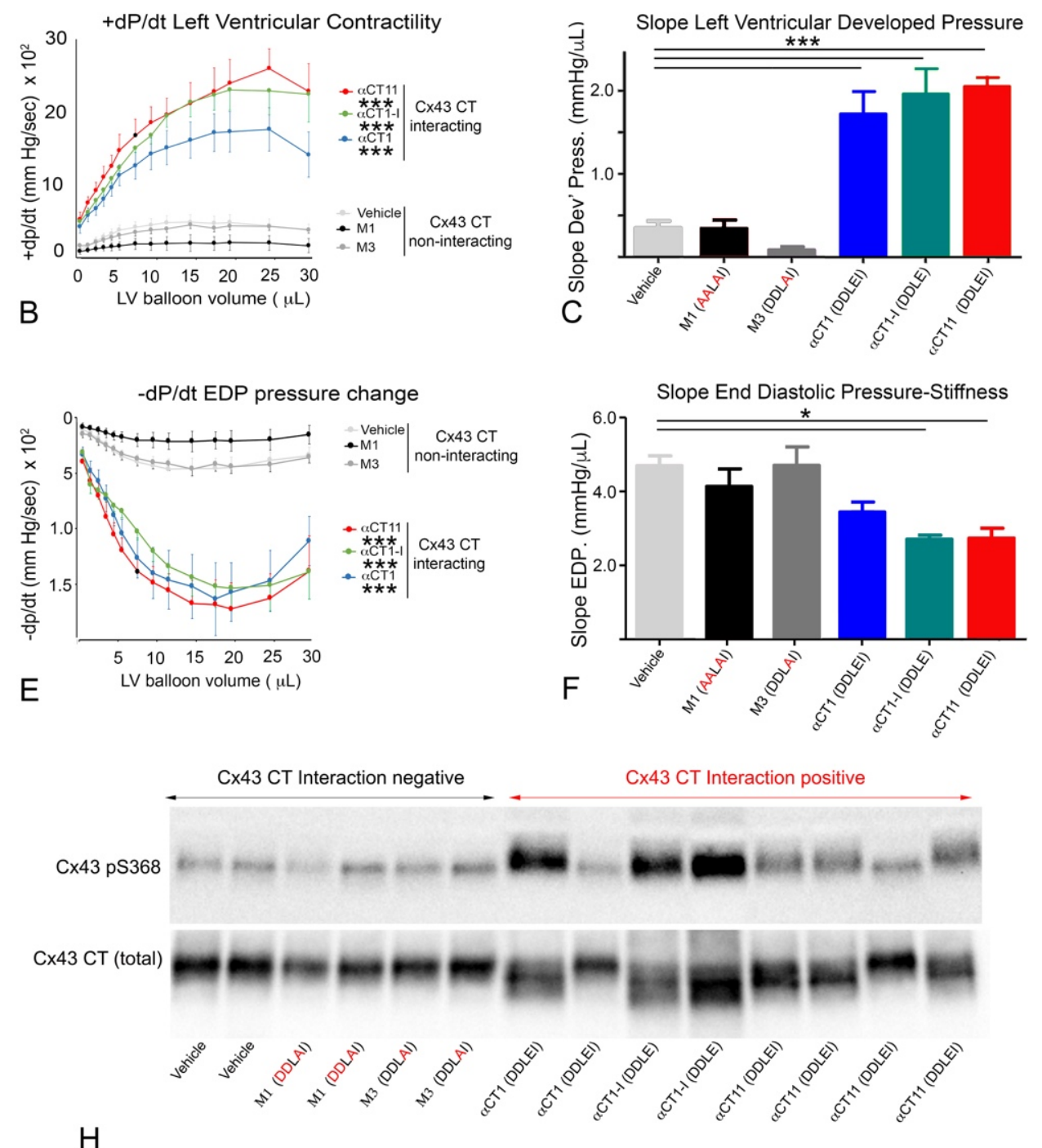

$\mathrm{H}$

Figure 7 
Left Ventricular Developed Pressure
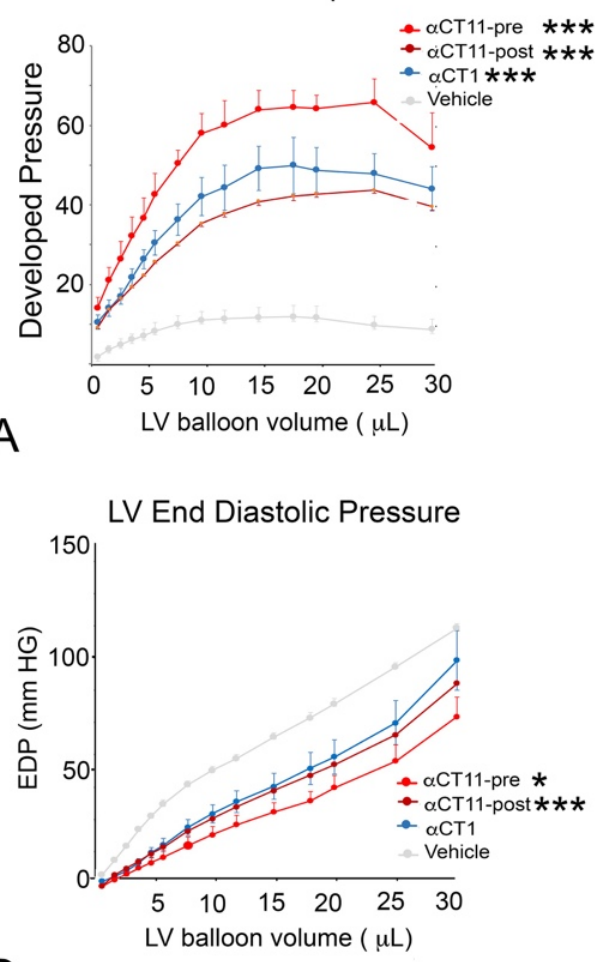

D

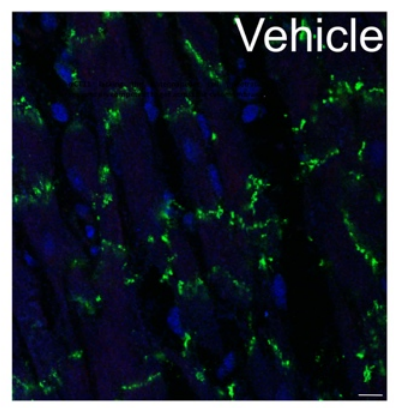

G

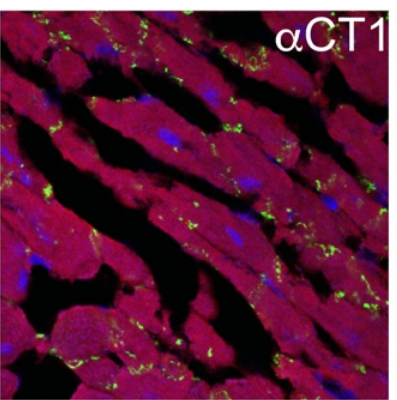

E
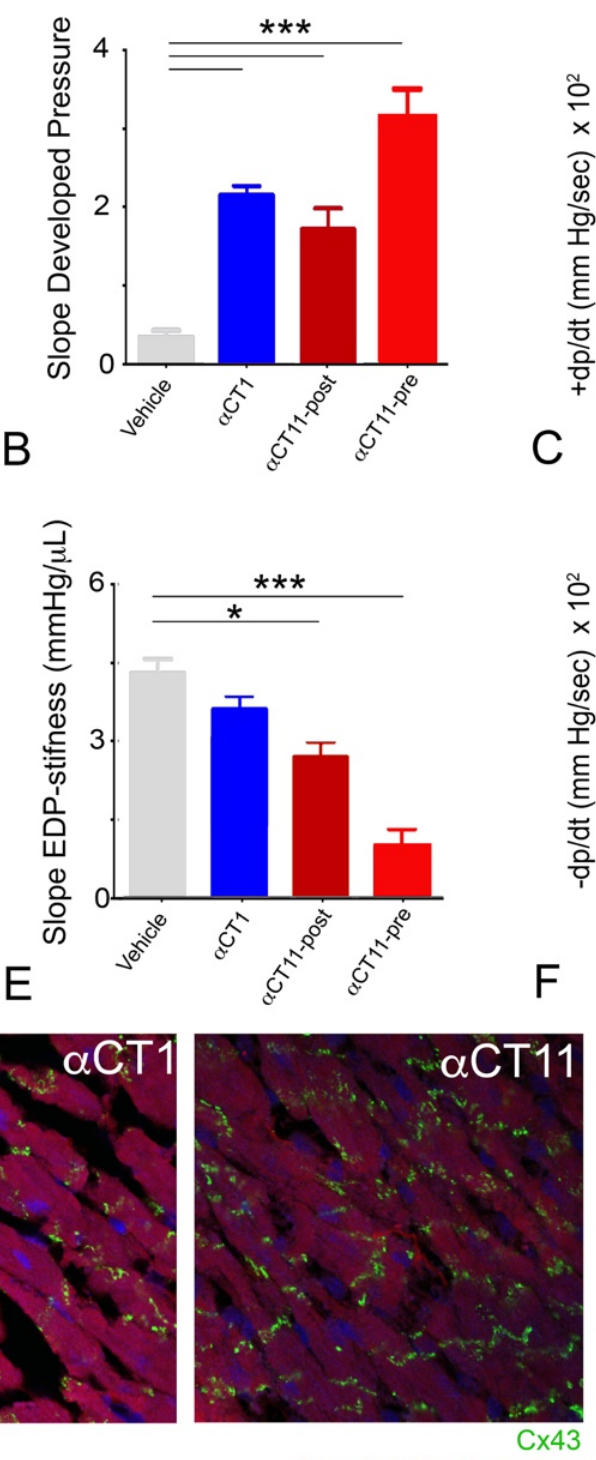

Streptavidin-Alexa fluor
$+\mathrm{dP} / \mathrm{dt}$ Left Ventricular Contractility

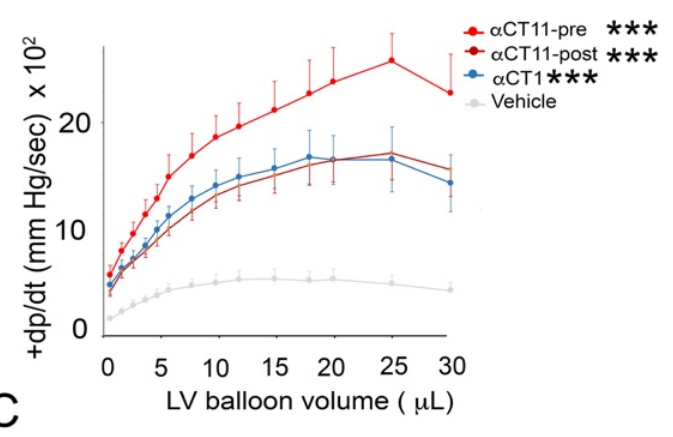

-dP/dt Left Ventricular EDP

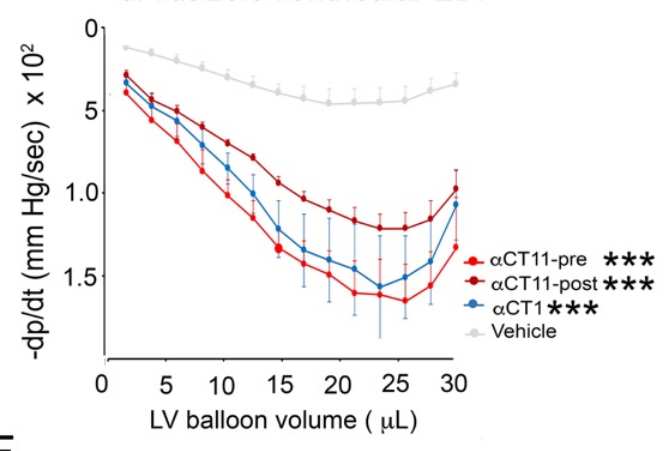

Figure 8

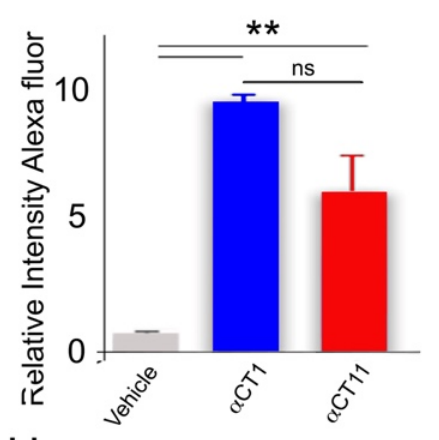

$\mathrm{H}$ 
bioRxiv preprint doi: https://doi.org/10.1101/668509; this version posted June 12, 2019. The copyright holder for this preprint (which was

not certified by peer review) is the author/funder, who has granted bioRxiv a license to display the preprint in perpetuity. It is made available under aCC-BY-NC-ND 4.0 International license.

\section{Langendorff Ischemia-Reperfusion Injury Protocol}

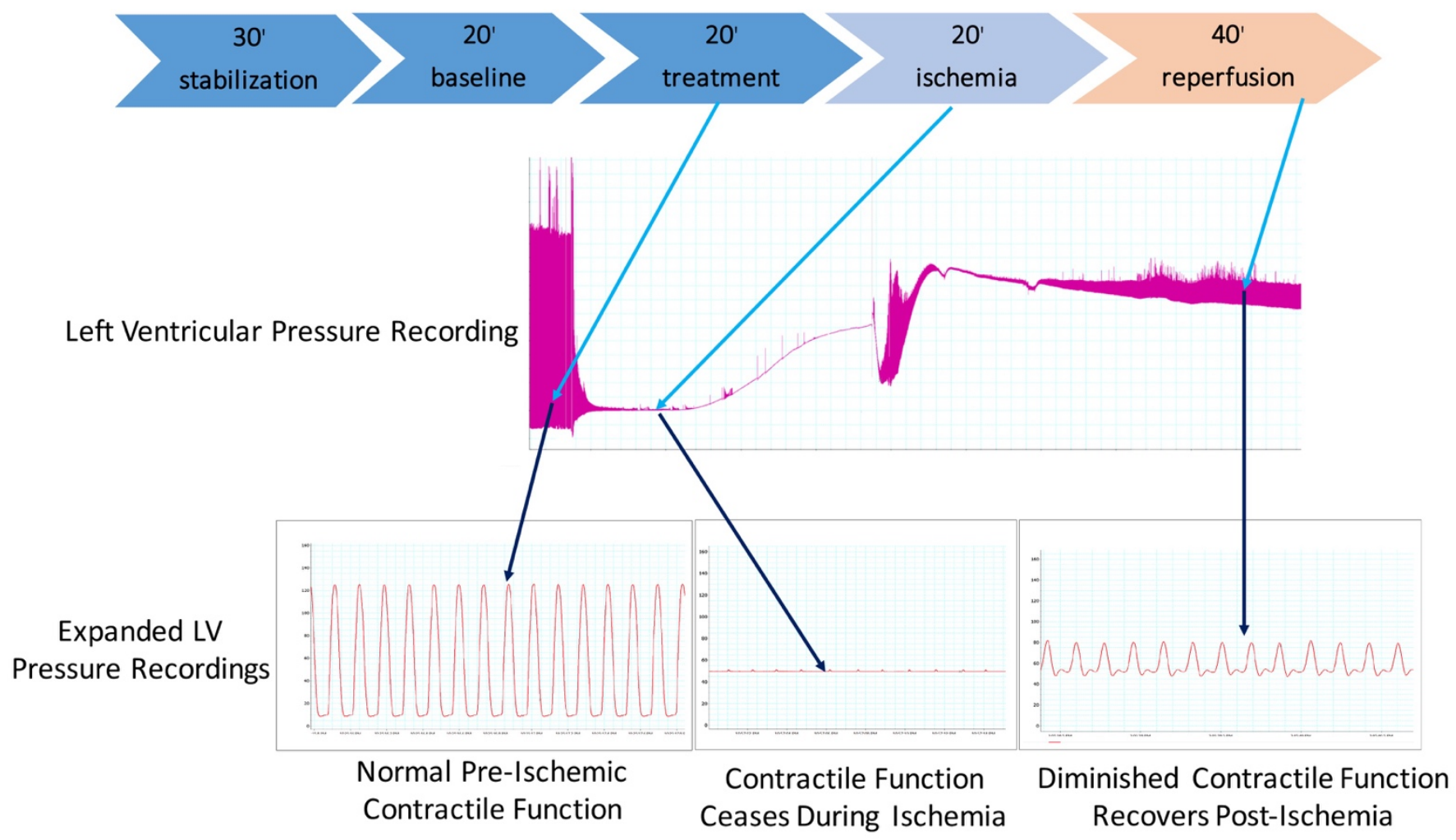

Supplemental Figure 1 


\section{Cx43 CT+aCT1}

5 10 25

Supplemental Figure 2 5 10

25 10 10

$\mathrm{Cx} 43 \mathrm{CT}+\alpha \mathrm{CT} 1 \mathrm{scr}$

Cx43 CT KK/QQ + $+\alpha \mathrm{CT} 1$ 
bioRxiv preprint doi: https://doi.org/10.1101/668509; this version posted June 12, 2019. The copyright holder for this preprint (which was

not certified by peer review) is the author/funder, who has granted bioRxiv a license to display the preprint in perpetuity. It is made available under aCC-BY-NC-ND 4.0 International license.
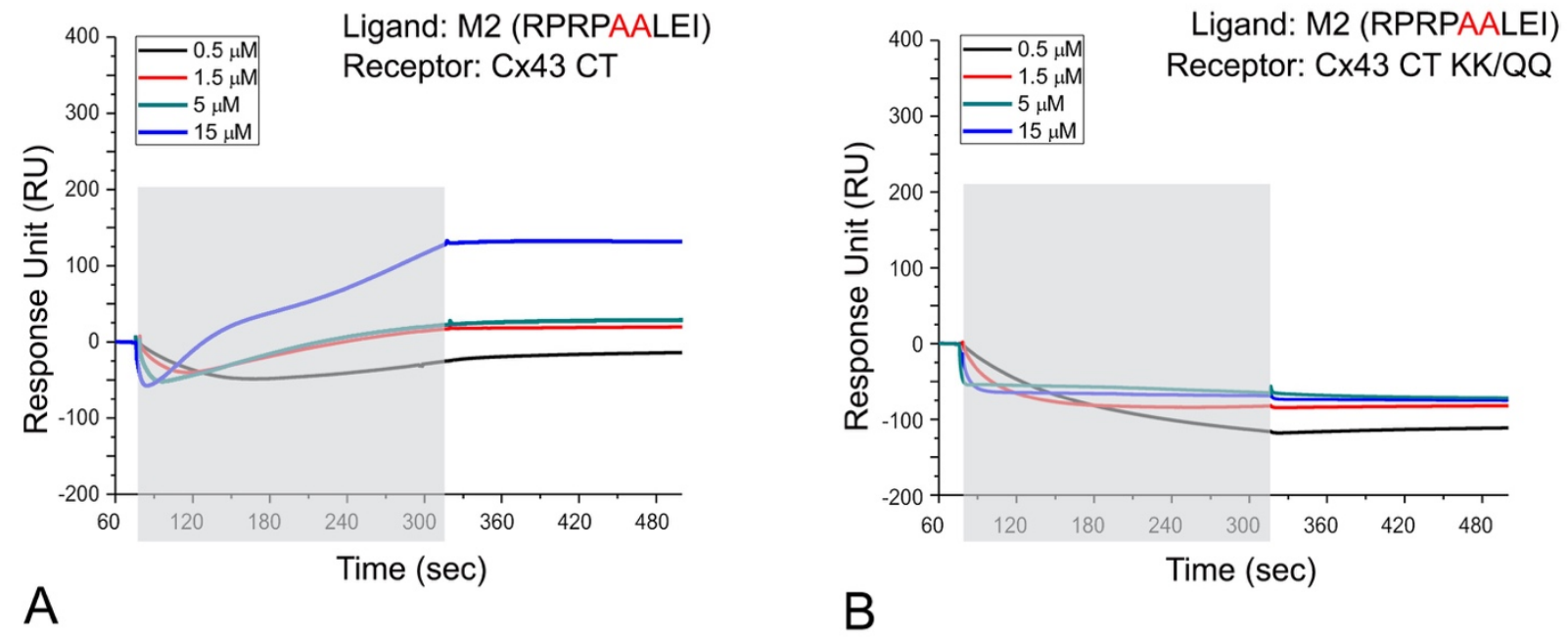

Supplemental Figure 3 